Running Head: IDEOLOGY

\title{
Ideology: The Psychological and Social Foundations of Belief Systems
}

\author{
Christopher M. Federico \\ Departments of Political Science and Psychology \\ University of Minnesota
}

Ariel Malka

Department of Psychology

Yeshiva University

Forthcoming, Oxford Handbook of Political Psychology (Third Edition)

Leonie Huddy, David Sears, Jack Levy, and Jennifer Jerit, Editors 


\begin{abstract}
Defining ideology as a system of functionally inter-connected political attitudes and beliefs, we review evidence concerning (1) the nature and origins of ideology in mass publics and (2) the social and interpersonal nature of the motives underlying ideological coherence. One key conclusion that we draw is that the links between psychological attributes and subsets of ideological attitudes sometimes appear to be organic and functional but other times appear to be conditional on how the relevant attitudes are packaged with other attitudes into socially constructed ideologies. A second key conclusion is that the social motives that induce citizens to pull diverse attitudes into ideological alignment may also, in polarized contexts, induce people to adopt non-political identities and selfperceptions that are congruent with ideological stereotypes. We recommend a focus on the implications of these processes for polarization and democratic stability.
\end{abstract}


Ideology -3

\section{Introduction}

The concept of ideology plays a central role in both normative and empirical understandings of political life. The importance of ideology derives in large part from the inherent complexity of politics, which invariably involves disputes about issues, values, and even understandings of reality in a variety of domains. Ideologies offer one way of managing this complexity. By providing leaders and citizens alike with comprehensive, organized frameworks for making sense of politics, ideologies supply political actors with ready-made judgments about the state of the world and many issues at once, while also furnishing an overarching narrative about why various political concerns fit together (Converse, 1964; Feldman, 2013; Lipset, 1960). Ideologies also explain and justify political reality. They provide rationales for why, and in what ways, the status quo should be preserved or changed (Bobbio, 1996; Jost, Federico, \& Napier, 2009; Sidanius \& Pratto, 1999). In short, ideologies confer structure, meaning, and cohesive rationales for action in a domain that would otherwise be intractably complicated.

Not surprisingly, ideologies especially animate the outlook of those most deeply invested in the business of politics. For example, ideologies have often received their most articulate and systematic expression in the work of political philosophers, pundits, and intellectuals, who have offered competing analyses of how and why societies function and how they should ideally be organized (Heywood, 2007; Laponce, 1981; Noel, 2014). Closer to the day-to-day conduct of political affairs, political parties and their leaders ('elites' in the argot of political science) rely on ideological abstractions to organize their platforms and structure political competition (Benoit \& Laver, 1996; Lijphart, 1990; Lipset \& Rokkan, 1967; Sniderman \& Bullock, 2004). Though the ideological work of party officials may not be as ornate as that of philosophers, it plays an essential role in lending coherence to party programs that span what would otherwise be hard-to-connect issue domains (Federico, 2021). Ideologies, in the practical partisan sense, allow a simpler choice 
between a manageable number of-oftentimes, two-_crowning postures,' rather than leaving citizens to make a multitude of judgments about specific issues (Converse, 1964; Zaller, 1992; see also Downs, 1957).

Though the normative significance of ideology and its importance to elite political discourse is clear, social scientists have disagreed about whether ideology plays a meaningful role in organizing the preferences of citizens in the mass public. Much of this disagreement stems from differences in opinion about what, precisely, it means to make use of ideology in one's political reasoning and behavior. For example, abundant evidence suggests that the average citizen does not consistently apply ideological principles in everyday political judgments or behavior, and in many cases citizens do not hold the kind of stable political preferences that ideology would imply (Converse, 1964, 2000; Federico, 2020; Kalmoe, 2020; Kinder \& Kalmoe, 2017). But this characterization of the mass public as 'innocent of ideology' has not gone uncontested. Other scholars, for example, argue that the apparent absence of ideological sophistication among everyday citizens is an artifact of poor measurement (e.g., Achen, 1975). Others note that diverse attitudes may be functionally inter-connected not by consistent application of abstract principles, but by service to a common set of underlying psychological motives (e.g., Jost, 2006). Still others emphasize identity processes as the mechanism that provides structural coherence to ideological outlooks among ordinary people (e.g., Federico \& Malka, 2018).

Though thinkers from a variety of disciplines have contributed useful analyses of ideology as a phenomenon (Heywood, 2007; Laponce, 1981), political psychology offers a unique, important perspective on the foundations, functions, and sweep of ideologies. In particular, political psychology provides crucial insights about how political preferences are ideologically organized and what processes give rise to the kinds of ideological belief systems we observe in various political contexts. Moreover, research on the psychological bases of ideology has shed light on the 
psychological needs, traits, and motives that attract individuals to one ideology or another-and how the relationships between psychological variables and political preferences vary across issue domains, persons, and situations.

In this chapter, we provide a broad overview of research on the political psychology of ideological belief systems. In the first section, we review work on the nature, structure, and psychological foundations of ideology. We begin by addressing basic questions of how to define and conceptualize ideology, and how it might be differentiated from other kinds of political orientations. We then discuss the most important ideological construct examined by political psychologists: the left-right continuum (Jost, Napier, \& Federico, 2009, 2013). While noting the significance of the leftright dimension, we discuss ways in which its role in shaping preferences in mass publics is conditional and review a growing body of evidence that ideology may be multidimensional rather than unidimensional in its psychological structure. Next, we cover research on the dispositional predictors of ideology, focusing on the core finding that individuals who score high (versus low) on measures of psychological rigidity and threat sensitivity tend to hold right-wing (versus left-wing) preferences within important political domains. We also discuss the boundary conditions of the dispositional model, noting that the relationship between psychological variables and political preferences is moderated to a substantial extent, and in theoretically coherent ways, by factors such as issue domain, political engagement, and national context. We then review research suggesting that individuals on both the left and right may rigidly defend their convictions, despite the tendency for conservative identifiers to score higher on dispositional indices of psychological rigidity.

In the second section of the chapter, we review theory and evidence regarding the social nature of ideology, with a particular focus on the social mechanisms that hold various elements of ideological belief systems together. We discuss various core social motives that lead people to adopt and act in accordance with different ideological identities and belief systems, including motives for 
bonding and intimacy with close others, motives to act in accordance with politically relevant social identities, and motives to defer to cues provided by trusted leaders. We also describe how the force provided by these social motives may encourage polarization and the sorting of electorates into ideologically disparate partisan camps. In turn, in the third section of the chapter, we discuss how ideological polarization and sorting may have feedback effects on other social divides and on psychological dispositions themselves. This is followed by the fifth section in which we describe the implications of the ideological phenomena reviewed in this chapter for comtemporary efforts to understand challenges to the integrity of democratic institutions.

In the final section, we conclude by summarizing and highlighting two key take-home messages of our review. The first is that links between psychological attributes and subsets of ideological attitudes sometimes appear to be organic and directly functional but other times appear to be conditional on how the relevant attitudes are packaged with other attitudes into sociallyconstructed ideologies (Federico \& Malka, 2018). Attention to this matter is important for understanding the psychological organization and societal implications of ideology. Second, we conclude that the social motives that give ideology its 'absorptive' power-its ability to draw substantively diverse attitudes into ideological alignment— are also likely, within polarized contexts, to induce people to adopt non-political identities and self-perceptions that are congruent with ideological stereotypes (Bakker, Lelkes, \& Malka, in press; Boston et al., 2018; Egan, 2020; Margolis, 2018b). How this phenomenon might perpetuate and aggravate polarization, and ultimately threaten democratic stability, is an important matter for researchers to attend to.

\section{The Nature, Structure, and Motivational Underpinnings of Ideology}

What is Ideology? 
We begin with a simple definitional question: what is ideology? Social scientists have pondered this question extensively, and in some ways there are as many definitions as there are scholars. However, a few key definitions cover the most important points (see Jost et al., 2009, p. 309). For example, political scientists Robert Erikson and Kent Tedin (2003) define ideology as a "set of beliefs about the proper order of society and how it can be achieved" (p. 64). More elaborately, Denzau and North (1994/2000) describe ideologies as "mental models" that "provide an interpretation of the environment and a prescription as to how that environment should be structured" (p. 24). In an effort at synthesis, Federico (2020) identifies three crucial defining features that are common to most definitions of ideology that political psychologists rely on: (1) ideologies are belief systems that tie an ideological identity together with specific attitudes, beliefs, and values in a functionally-interdependent way across multiple domains (e.g., Brandt \& Sleegers, 2021); (2) ideologies are socially shared among members of a group and reflect the life circumstances of people living in a specific social context; and (3) ideologies are both descriptive and prescriptive, in that they explain why society is the way it is and make normative statements about what society should ideally be like.

Though most conceptualizations of ideology share these basic features, they sometimes differ in the extent to which they approach ideology from a more functional perspective versus a “critical" one (Jost et al., 2009, 2013). The functional perspective usually takes a "value-neutral" tone, focusing on the organizational and interpretive role of political belief systems (e.g., Converse, 1964; Knight, 1999; see also Brandt \& Sleegers, 2021). This approach derives variously from sociological functionalism and from formal treatments of ideology in political science that emphasize the role of ideology in simplifying political choices and systems of party competition (e.g., Downs, 1957; Hinich \& Munger, 1994; see also Lipset, 1960; Lijphart, 1990; Benoit \& Laver, 1996; Lipset \& Rokken, 1967). In contrast, the critical perspective focuses more on the "system-justifying" 
role of ideologies — that is, on how ideologies may hide, excuse, or legitimize oppressive social arrangements. This approach descends in part from the classical Marxist view of ideology, which observed "the ideas of the ruling class are in every epoch the ruling ideas" (Marx \& Engels, 1846/1970). Continuing in this vein, later theorists spoke similarly of ideology as a kind of "cultural hegemony" (Gramsci, 1971) or as "systematically distorted communication" (Habermas, 1989). In contemporary political psychology, the critical perspective is incorporated most strongly into system justification theory (Jost, 2020) and social dominance theory (Sidanius \& Pratto, 1999), which argue that members of subordinate social groups will be less likely to challenge systems of stratification or pursue the interest of their own group if they endorse beliefs suggesting that the unequal status quo is "fair" or morally justified. Often, the ideologies described by these models are narrower in nature than the broad worldviews that the belief systems perspective focuses on (e.g., the Protestant work ethic as a justification for economic inequality, as opposed to a broader conservative ideology covering both economics and other domains).

The core claims of these two perspectives on ideology do not mutually exclude one another; ideologies can be both belief systems and tools for justifying existing states of affairs. Though we touch on both treatments of ideology in this chapter, we focus on ideologies as generalized, interlinked belief systems (e.g., Converse, 1964, 2000; Eagly \& Chaiken, 1993). We do so in part to differentiate ideologies from other attitudes, values, and beliefs that may justify the status quo in a specific fashion but do not tie together positions across multiple issue domains in an interlocking way. But more importantly, we do so in order to clearly differentiate belief systems per se from the underlying psychological motives or institutional or group-interest functions that belief systems might sometimes serve. In other words, we do not make any restrictive assumption that a belief system only counts as 'ideology' if it serves a system- or group interest-justifying purpose. 
Ideologies, then, are broad overarching structures comprised of multiple idea-elements, that are socially shared and anchored in identity. Political psychologists have in turn identified several core components of these structures, ranging from issue positions at the most concrete level to higher-order values and principles at the most abstract level (Feldman, 2013; Goren, 2012; Peffley \& Hurwitz, 1985). A few key distinctions are especially important here. First, public-opinion research frequently distinguishes between ideology in the 'symbolic' or 'philosophical' sense and ideology in the 'operational' sense (Ellis \& Stimson, 2012; Free \& Cantril, 1967; Stimson, 2004). Symbolic ideology refers to identification with a particular ideological category (e.g., conservative or liberal; Ellis \& Stimson, 2012), whereas philosophical ideology refers to an abstract posture regarding social life (e.g., a libertarian preference for smaller government or a conservative preference for a more cautious orientation toward social change; Free \& Cantril, 1967). In contrast, operational ideology refers to the general tilt of one's issue preferences, averaging across specific policy choices (e.g., whether one prefers more or less government intervention in the economy across various issues; Stimson, 2004). Importantly, these facets of ideology do not always hang together. For example, in the aggregate, Americans are simultaneously more likely to identify symbolically as 'conservatives' but operationally prefer the 'liberal' option of greater government spending across issues; indeed, a large proportion of individual citizens who identify as conservatives also favor greater spending (Ellis \& Stimson, 2012; see also Gidron, 2020). Moreover, not all of these facets are equally central to individuals' belief systems. In this respect, the symbolic components of ideology (e.g., ideological identifications) are more strongly linked than operational issue positions with a larger number of belief-system elements and with actual voting behavior (e.g., Brandt, Sibley, \& Osborne, 2019; Brandt \& Sleegers, 2021).

Second, researchers have distinguished between the discursive superstructure and motivational substructure of ideologies (Jost, Federico, \& Napier, 2009; see also Federico, 2021; Federico \& Malka, 
Ideology -10

2018). The discursive superstructure of an ideology is its ideational content, consisting of the specific issue attitudes, values, and beliefs that go along with an ideological identity in a particular political context; it is the symbolic and positional content of an ideology. The motivational substructure of an ideology is the set of psychological motives and characteristics that attract people to one ideological posture or another (e.g., to the political left versus the political right). These include traits that reliably incline people to the left or right in particular domains; for instance, as we note in more detail below, strong needs for security and certainty tend to predict conservative positions in many

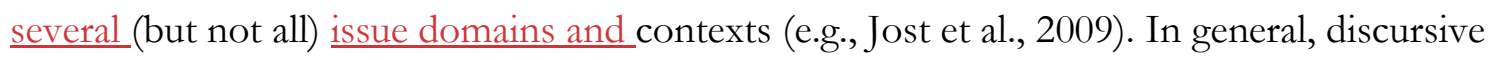
superstructures are socially constructed networks of commitments, forged most strongly by the creative work of intellectuals and political elites (Converse, 1964; Noel, 2014). As such, they vary from one context to the next. The psychological variables that comprise the motivational substructure are more universal. For example, they include personality traits that are relatively similar across human populations (e.g., Hibbing, Smith, \& Alford, 2014; Mondak, 2010). That said, the dispositions that make up the motivational substructure vary in their relationship with ideological preferences as a function of issue domain, political engagement, and contextual factors, as we shall see. For example, while those high (versus low) in needs for certainty are more attracted to conservative (versus liberal) positions on several issues, this relationship breaks down when the certainty-providing meaning of these conservative positions is not clear (e.g., Johnston, Lavine, \& Federico, 2017).

\section{A Core Ideological Construct: The Left-Right Dimension}

One of the most important questions addressed by political psychologists interested in belief systems is how best to characterize individual differences in ideology. Though the nature of ideological variation is a topic of much debate (see Carmines \& D’Amico, 2015; Duckitt \& Sibley, 2010; Feldman \& Johnston, 2014; Lewis, 2019), the most common assumption among researchers is 
that ideology varies on a unidimensional, left-right basis (Jost, 2006; see also Federico, 2020).

Substantively, this schema is thought by many to contrast belief systems characterized by openness to social change and a preference for greater equality on the left and by preferences for stability and hierarchy on the right (Jost et al., 2009, 2013; Lipset, 1960). This characterization of ideology has its roots in the specifics of European history: indeed, the terms "left" and "right" refer back to the seating locations of radicals and conservatives in the French National Assembly in the late $18^{\text {th }}$ century (Bobbio, 1996).

The left-right division plays a dominant role in the organization of political debate in many cultures (Benoit \& Laver, 2006; Kitschelt, Luna, Rosas, \& Zechmeister, 2010; Knight, 1999; McCarty, Poole, \& Rosenthal, 2006), and it has also been the focus of most behavioral and psychological research on the nature and foundations of ideological affinity (Federico, 2020). The left-right distinction is especially relevant to how governing elites and other opinion leaders organize and explain their preferences and decisions (Campbell et al., 1960; McCarty, Poole, \& Rosenthal, 2006; Noel, 2014). Similarly, the most engaged segments of the mass public are more likely to rely on the left-right schema to organize their preferences and perceptions (Converse, 1964; Kalmoe, 2020; Kinder \& Kalmoe, 2017). The practical importance of the left-right dimension is not surprising. A venerable line of formal analysis in political science has consistently noted that reliance on a single ideological dimension has the salutary property of simplifying political choices and making communication and understanding of politics more manageable in the face of coordination problems and human cognitive limitations (Downs, 1957; Hinich \& Munger, 1994; Sniderman, Brody, \& Tetlock, 1991). By collapsing multiple dimensions of political conflict (spread across a potentially large number of issues) into a single axis of disagreement, left-right competition should be especially helpful to those most involved in the operational work of politics. In other words, it may be institutionally adaptive. 
Though functional, the left-right distinction is contingent and fluid (Federico \& Malka, 2018). Indeed, there is substantial debate about the relative importance of a durable substantive core versus alterable coalition-justifying elements to left-right ideology (Jost, 2006; Federico \& Malka, 2018; Lewis, 2019; Morgan \& Wisneski, 2017; Noel, 2014). Some work emphasizes the seemingly durable aspects of left-versus right ideology. In particular, the familiar divide between a preference for equality and an inclination to seek change (on the left) versus favoring hierarchy and the status quo (on the right) is arguably the most consistent symbolic axis of left-right competition-a pattern rooted in the fact that hierarchical social arrangements (whether aristocratic or capitalistic) have historically anchored the status quo in many societies (Bobbio, 1996; Federico, 2020; Jost, 2009; Jost et al., 2009; Lipset, 1960; McClosky \& Zaller, 1984). In contrast, other symbolic and programmatic differences between the left and right show greater variance across societies and time periods, making it unwise to assume that the content of the left-right divide is a fact of nature (see Lewis, 2019; see also Federico \& Malka, 2018). Policy positions, value emphases, and ideological rhetoric change over time as a function of elite coalition-building and new challenges (Noel, 2014). For example, in debates over health care policy in the United States, support for an individual mandate to purchase health insurance shifted from being a "conservative" position to a "liberal" one, as conservatives adjusted their stance on the basis of challenges offered to the status quo by political actors on the left (Johnston et al., 2017). Similarly, center-right parties in advanced democracies have strategically shifted in their attitudes toward democracy, regulation of the free market, and other matters over time in order to best protect the interests of elite groups amid changing circumstances (Gidron \& Ziblatt, 2019). Within the United States, the adjustment of "conservatism" to the rise of Donald Trump is an object lesson in the flexibility with which core ideological constructs are popularly defined (Hopkins \& Noel, 2021; Lewis, 2019). 
Ideology -13

With both its durable and its malleable components, the left-right dimension has clearly been central to the way elite ideological differences have been structured in many places and times. However, its role in belief-system structure within mass publics is more complicated and contested (Converse, 1964; Kalmoe, 2020; Kinder, 2006; Kinder \& Kalmoe, 2017; see also Federico \& Malka, 2018). As studies of public opinion from a variety of advanced democracies over multiple decades suggest, many citizens (1) do not fully understand the conceptual distinction between left and right, (2) do not spontaneously use the left-right schema to describe political actors and events, and (3) do not hold ideologically-constrained positions across issues (Baldassari \& Gelman, 2008; Converse, 1964; Kinder \& Kalmoe, 2017). Moreover, as Philip Converse (1964) famously found, many citizens in the 1950s showed low levels of attitude stability on specific issues, suggesting that their opinions were effectively "non-attitudes" that lack a broader ideological anchor. Of course, the extent and kind of ideological structuring varies across contexts and time periods (Baldassari \& Goldberg, 2014; Levendusky, 2009; Malka, Lelkes, \& Soto, 2019). Moreover, researchers have argued that mass publics may show greater evidence of stable, ideologically structured attitudes once random error in survey measures is statistically accounted for (Achen, 1975; Ansolabehere, Rodden, \& Snyder, 2008; Erikson, 1979; Hill \& Kriesi, 2001; Judd \& Milburn, 1980). Regardless, it is clear that left-right belief system structure in mass publics is found primarily among the stratum of citizens who are most knowledgeable of and interested in political affairs (Converse, 1964; Federico, 2021; Kalmoe, 2020; Sniderman, Brody, \& Tetlock, 1991; Zaller, 1992). Compared to their less-engaged compatriots, these individuals are more likely to have received and accepted elite ideological signals about 'what goes with what' (Kinder \& Kalmoe, 2017; see also Freeder, Lenz, \& Turney, 2019; Groenendyk, Kimbrough, \& Pickup, 2020). Moreover, the traditional left-right system of belief organization is relatively uncommon globally, especially outside "WEIRD” (i.e., Western, educated, industrialized, rich and democratic) nations (Malka, Lelkes, \& Soto, 2019; Marks et al., 2006; see also Federico, 
2021). For example, using World Values Survey data collected in ninety-nations, Malka and his colleagues find that the modal societal pattern is for conservative cultural preferences to be associated with left-leaning (rather than right-leaning market-oriented) economic preferences (Malka et al., 2019).

Taken together, these findings suggest that the left-right schema is an important basis for ideological variation, but also one whose reach is limited in significant ways (Morgan \& Wisneski, 2017). In this respect, the division between left and right, while common, is not a fact of nature. It is not fixed — and neither are its relationships with other attitudes, identities, and psychological traits, a point we will return to below. The set of ideological packages available in a given society are social constructions. In large part, they reflect the discursive work of parties and their leaders, who assemble different issue positions and values into the competing ideological frameworks that citizens choose from (Federico \& Malka, 2018; Malka \& Soto, 2015; Sniderman \& Bullock, 2004); and intellectuals and pundits, who provide philosophical justifications for the ideological commitments that unify various political coalitions (Noel, 2014). As Converse (1964) noted long ago, ideologies most commonly derive their coherence from social cues provided by opinion leaders, rather than emerging solely on the basis of formal logic or bottom-up psychological motivations. This appears to be the case for the left-right schema as well, whose organization reflects the ways in which political elites have structured political competition in modern Western democracies (Federico \& Malka, 2018; Jost, 2006).

\section{Beyond the Left-Right Dimension: Multidimensional Conceptions of Ideology}

Noting limits to the left-right dimension's explanatory reach, other perspectives on ideological variation suggest the existence of multiple dimensions of ideology (Federico, 2021; Feldman \& Johnston, 2014; Malka et al., 2019). Though there are analyses that suggest higher numbers of ideological dimensions (Carmines, Ensley, \& Wagner, 2012; Layman \& Carsey, 2002; 
Ideology -15

Park, 2018), the most common multidimensional approach to ideology posits the existence of two ideological dimensions, which emerge in a bottom-up fashion in factor-analytic examinations of the structure of sociopolitical attitudes. The way these dimensions are defined and interpreted varies across disciplines. Within psychology, the first dimension has tended to broadly correspond with preferences for more versus less equality, whereas the second has corresponded with preferences for cultural openness and autonomy versus tradition, order, and uniformity (Duckitt, 2001; Federico, 2021; Schwartz, 1992). In a sense, this bidimensional model disaggregates the two facets of ideological difference that the unidimensional model joins together (i.e., orientations toward equality and openness to change versus hierarchy and tradition; Jost, 2009), and argues that they vary in the extent to which they consistently overlap (Federico \& Malka, 2018). Evidence for this bidimensional structure can be found across a variety of domains, most notably in the organization of value preferences and worldviews (e.g., Braithwaite, 1997; Duckitt, 2001; Schwartz, 1992; Stangor \& Leary, 2006).

Within political science, these dimensions often deal with variation in the types of policy preferences queried in public opinion surveys. In particular, factor analyses of such survey data find that economic preferences (i.e., over government intervention in the economy and support for social welfare) and sociocultural preferences (i.e., over religion, multiculturalism, and traditional values) reliably fall on different factors (e.g., Carmines, Ensley, \& Wagner, 2012; Evans, Heath, \& Lalljee, 1996; Feldman \& Johnston, 2014; Fleishman, 1988; Knoke, 1979; Shafer \& Claggett, 1995; Treier \& Hillygus, 2009). Consistent with the idea that these two-dimensional models are, to a degree, parallel, research suggests that attitudes toward economic issues relate more strongly to the egalitarianism value dimension, while attitudes toward sociocultural issues relate more strongly to the 
openness versus tradition value dimension (Duckitt \& Sibley, 2010; see also Federico, 2021, Johnston et al., 2017, for reviews). ${ }^{1}$

Duckitt and colleagues' dual-process model of ideology and prejudice (Duckitt, 2001;

Duckitt \& Sibley, 2010) provides perhaps the most systematic account of how and why attitudes and beliefs can be characterized using two dimensions. The dual-process model argues that the equalityinequality and openness-tradition dimensions can be captured respectively by social dominance orientation (SDO; a general preference for group-based hierarchy; Sidanius \& Pratto, 1999) and rightwing authoritarianism (RWA; an inclination toward deference to ingroup authorities, conventionalism, and hostility toward outsiders and norm-violators; Altemeyer, 1998). In turn, the model suggests that these two "ideological attitude systems" are rooted in distinct worldviews and traits. Whereas the $\mathrm{SDO} /$ equality dimension rests on a view of the world as competitive and ruthless and on toughminded personality traits, the RWA/tradition dimension rests on a view of the world as dangerous and conformity-related traits (Duckitt, 2001). Put another way, the dual-process approach suggests that the SDO dimension reflects competitive, dominance-oriented motives, and that the RWA dimension reflects needs for security, safety, and certainty.

Though distinct, these two dimensions do overlap somewhat—albeit to a varying extent across political environments and individuals (Federico, 2020, 2021; Petersen, 2015; Weeden \& Kurzban, 2014). In some cases, the two dimensions are constrained in the usual 'left-right' way, such that preferences for equality are aligned with cultural openness and preferences for hierarchy are aligned with support for tradition and the status quo. In other cases, they are not. As Federico and Malka (2018) note, the packaging of the two dimensions depends in large part on a polity's history

\footnotetext{
${ }^{1}$ Qualifying this somewhat, it is important to note that valuing of equality applies to both the cultural and economic policy domains (Federico \& Malka, 2018; Malka, Lelkes, \& Holzer, 2017) and that a reliable link between a general and consistently applied orientation toward change and substantive aspects of left-right ideology is questionable (Proch, Elad-Strenger, \& Kessler, 2019).
} 
and on how its elites tie together concerns from different political domains. The standard, 'matched' left-right alignment of the two dimensions prevails in nations that are more economically developed, secularized, and culturally liberal, and in nations that were not part of the former communist bloc (Malka et al., 2014; 2019). In these countries, elites have tended to pair egalitarian economic positions with more culturally liberal social positions. However, outside of this set of nations, it is actually more common for egalitarianism and left-wing economic views to be slightly positively correlated with traditionalism and conservative cultural views (or vice versa) — a pattern Malka, Lelkes, and Soto (2019) refer to as the 'protection versus freedom' belief system organization.

However, even within nations where egalitarianism is aligned with cultural openness and leftwing (versus right-wing) economic positions are aligned with left-wing (versus right-wing) cultural positions, left-right consistency is not found to the same extent among all citizens. Though left-right packaging predominates among political elites and activists in these countries (Converse, 1964; Jennings, 1992), only those segments of the mass public that are attentive to signals from political elites about what goes with what show clear left-right alignment across dimensions and issue domains (Federico, 2021; Feldman \& Johnston, 2014; Layman \& Carsey, 2002; Malka et al., 2019). In sum, social and historical context—and elite opinion leadership in particular-play a key role in determining how the two core dimensions of ideological variation align with one another.

\section{The Dispositional Bases of Ideology}

Besides examining the nature of ideological differences, political psychologists have also taken a perennial interest in the dispositional bases of ideological affinity — that is, the psychological motives and characteristics that predict ideological orientations (Jost et al., 2003, 2009, 2013; see also Federico \& Malka, 2018). Though the precursors of this approach go back as far as classical sociology in the modern era (e.g., Weber, 1948; see also Gerth \& Mills, 1953; Lasswell, 1948), the key impetus for work in this area goes back to post-war efforts to identify the antecedents of 
support for fascist ideology—most notably, early work on the authoritarian personality (e.g., Adorno, Frenkel-Brunswik,, Levinson, \& Sanford, 1949; see also Allport, 1954). Subsequently, this approach was extended in order to make sense of the dispositional antecedents of extremism in general (Eysenck, 1954; Lipset, 1960; Rokeach, 1960) and 'normal' left-right variation of the nontotalitarian sort (McClosky, 1958; Tomkins, 1963; Wilson, 1973).

Though work on the dispositional roots of ideology went out of style for some time, it was revived shortly after the turn of the century due in no small part to the work of social psychologist John Jost and his colleagues (Jost, 2009; Jost et al., 2003, 2009). The main conclusion that has been drawn from this contemporary body of work is that variables reflecting high (versus low) levels of psychological rigidity and threat sensitivity predict right-wing (versus left-wing) ideological preferences (Federico, 2021; Jost et al., 2009). This conclusion is sometimes characterized as the 'rigidity of the right' perspective (Federico, 2021; Malka, Lelkes, \& Holzer, 2017). An exhaustive review of the relevant literature would require a chapter in and of itself, so we refer the reader to canonical reviews of research on this topic (e.g., Federico \& Malka, 2018; Jost et al., 2003, 2009, 2013; Jost, 2017) and provide only a brief summary of evidence and ongoing debates here.

First of all, one of the most examined dispositional predictors of political ideology is authoritarianism or the authoritarian predisposition, which reflects individual differences in deference to group authority and ingroup norms (Adorno et al., 1950; Altemeyer, 1998; Duckitt, 2001; Duckitt \& Bizumic, 2013; Stenner, 2005). Individuals high in authoritarianism have stronger needs for security and are more sensitive to threat (Duckitt \& Sibley, 2010; Feldman, 2003; Hetherington \& Weiler, 2009; Lavine et al., 1999; Lavine, Lodge, Polichak, \& Taber et al., 2002). As such, those high (versus low) in authoritarianism tend to prefer conservative (versus liberal) positions on cultural matters and tend to identify as politically conservative, perhaps to avoid the risks associated with deviation from 
the status quo (Federico, Fisher, \& Deason, 2011; Federico, Hunt, \& Ergun, 2009; Feldman, 2003; Hetherington \& Weiler, 2009; Jost et al., 2009).

Another variable commonly linked to ideological differences is the need for cognitive closure (Kruglanski, 2004; Kruglanski \& Webster, 1996; Kruglanski, Pierro, Mannetti, \&DeGrada, 2006), a tendency to avoid uncertainty by "seizing" more on available information as quickly as possible to draw conclusions and by "freezing" on those conclusions even in the face of a changed information environment. Research consistently suggests that individuals high (versus low) in need for closure are more likely to hold conservative political identities and cultural issue preferences (Federico, Deason, \& Fisher, 2012; Federico \& Goren, 2009; Jost et al., 2003, 2009; Kemmelmeier, 1997; Van Hiel, Pandelaere, \& Duriez, 2004; Van Hiel et al., 2010; see also Ruisch \& Stern, 2020). Related findings suggest links between cognitive flexibility and analytic and exploratory thinking styles, on one hand, and liberal political identity and (mostly cultural) stances, on the other (e.g., Jost, Sterling, \& Stern, 2017a; Pennycook et al., 2020; Zmigrod et al., 2021; see also Ruisch, Shook, \& Fazio, 2020; Shook \& Fazio, 2009).

Similar patterns arise in studies of personality, values, and morality. With respect to personality, studies using the five-factor model of personality (McCrae, 1996) consistently find that individuals high in openness to experience are more likely to hold liberal identifications and liberal preferences on many issues, whereas those high in conscientiousness are more likely to hold conservative identifications and issue preferences (e.g., Carney, Jost, Gosling, \& Potter, 2008; Gerber et al., 2010, 2011; McCrae, 1996; Mondak, 2010; for analogous results using measures of open-minded thinking, see Pennycook et al., 2020). Given the conceptual content of these traits, these patterns are consistent with the assumptions of the rigidity-of-the-right model: openness implies stronger tolerance of uncertainty and risk, whereas conscientiousness implies an emphasis on duty and restraint (McCrae \& Costa, 2003). 
Ideology -20

With respect to values, work using Schwartz's (1992) model of human values finds that a preference for security-providing conservation values (i.e., tradition, conformity, and security) over exploration-oriented openness values is reliably associated with right-wing (versus) left-wing political identifications and cultural preferences (i.e., stimulation and self-direction; Caprara, Schwartz, Capanna, Vechionne, \& Barbaranelli, 2006; Goren, 2012; Malka, Soto, Inzlicht, \& Lelkes, 2014; Schwartz, 1992, 2007; Thorisdottir et al., 2007). Finally, with respect to morality, research relying on moral foundations theory finds that individuals who place greater importance on binding moral concerns linked to group loyalty, deference to authority, and moral purity — concerns linked to shoring up communal social ties in the face of insecurity and danger-are more likely to hold conservative political identities and cultural attitudes (Graham, Haidt, \& Nosek, 2009; Haidt, 2012; Koleva, Graham, Iyer, Ditto, \& Haidt, 2012; see also Federico et al., 2013; Federico \& Weber, 2013). Large-scale meta-analytic studies conducted in recent years provide evidence consistent with these basic patterns, with some caveats that we will return to below. For example, Jost, Stern, Rule, and Sterling (2017b) examined data from 134 studies and found "small-to-moderate" relationships between variables linked to the salience of fear and threat and support for several right-wing policies, parties, and leaders. Similarly, Jost, Sterling, and Stern (2017a) aggregated results from 181 samples including 133,796 participants and observed significant relationships (1) between measures of needs for structure and order, need for closure, intolerance of ambiguity, rigidity, and dogmatism and several right-wing preferences and (2) between measures of integrative complexity, analytic thinking, need for cognition, and uncertainty tolerance and several liberal preferences.

Recent research using methods other than meta-analysis finds roughly similar patterns. For instance, Zmigrod and her colleagues (2021) used a data-driven approach based on Bayesian and drift-diffusion modeling techniques to map relationships between cognitive and personality 
Ideology -21

dimensions and ideology. ${ }^{2}$ In addition to finding that cognitive and personality variables consistently had stronger relationships with ideology than demographics did, they also found that conservative attitudes were associated with greater caution in perceptual decision-making and that cultural conservatism was linked with information processing styles that were less flexible, complex, and reliant on working memory and with lower levels of risk-taking and greater risk perception.

When evaluating evidence for the rigidity-of-the-right model, there are nevertheless some recurring methodological and interpretative issues whose implications must be considered. Malka, Lelkes, and Holzer (2017) documented three of these: content overlap between psychological and political measures, insufficient attention to differences in the psychological correlates of cultural and economic political attitudes, and lack of attention to the role of political information environment in conditioning links between psychological variables and political attitudes. Occurrences of these issues are too numerous to document comprehensively here (see Malka et al., 2017), but it will suffice to provide a few examples. Research on the salience of fear and threat frequently uses measures of these constructs that are overtly politicized, such as threat of terrorism and loss of white majority status (Jost et al., 2017). When attention is paid to the specifically politicized nature of different threats, results do not show a directionally consistent relationship between threats and political orientation (see Brandt, Turner-Zwinkels, Karapirinler, Van Leeuwen, Bender, van Osch, \& Adams, 2020; Crawford, 2017; Hatemi \& McDermott, 2021). In addition, the rigidity-of-the-right model often fails to account for why psychological variables that supposedly predict a broad-based conservative orientation often fail to predict right-wing positions in the economic domain, which is recognized by political scientists as central to left-right-differences in most advanced democracies

\footnotetext{
${ }^{2}$ Drift-diffusion modeling uses accuracy and reaction-time data from cognitive tasks as input and derives latent variables reflecting different aspects of cognitive performance, including average rate of evidence accumulation, how individuals balance speed versus accuracy, and speed of stimulus processing and response execution (Zmigrod et al., 2021, p. 3).
} 
Ideology -22

(see Duckitt \& Sibley, 2010; Johnston et al., 2017; Malka et al., 2014). Finally, the strength and even direction of relationships between psychological attributes and political attitudes vary considerably across factors that serve as proxies for exposure to different political information environments (Federico \& Malka, 2018). Below we discuss research on moderators of disposition-politics links that is attuned to these issues.

Moderators of the Relationship Between Dispositions and Ideological Preferences

Though the relationship between high (versus low) psychological rigidity and threat sensitivity and many right-leaning (versus left-leaning) preferences is well-established at this point, evidence also increasingly suggests that these relationships are moderated by a number of individual and contextual factors, in predictable and theoretically coherent ways. Like the literature on dispositional variables and ideology itself, this body of work is extensive (see Federico, 2021; and Federico \& Malka, 2018, for more exhaustive reviews). Below, we cover the key types of moderators that have been examined.

Issue domain. Perhaps the most important moderator is the type of political issue measured in a given analysis. As noted previously, political preferences are usefully described in terms of a twodimensional structure corresponding in the policy realm to economic issues and sociocultural issues (Duckitt \& Sibley, 2010; Feldman \& Johnston, 2014). In general, variables indicative of psychological rigidity and threat sensitivity more strongly predict ideological conservatism in the sociocultural domain than the economic domain; relationships between these dispositions and economic preferences are weak and inconsistently signed (Federico, Johnston, \& Lavine, 2014; Federico \& Malka, 2018; Johnston et al., 2017; Malka \& Soto, 2015; see also Costello \& Lilienfeld, 2020). This pattern is found for authoritarianism (Cizmar et al. 2014; Feldman \& Johnston, 2014), need for closure (Chirumbolo, Areni, \& Sensales, 2004; Federico, Ergun, \& Hunt, 2014; Kossowska \& Van Hiel, 2003; Van Hiel et al., 2004; Yilmaz \& Saribay, 2016), and endorsement of conservation 
versus openness values (Duckitt, 2001; Duriez, Van Hiel, \& Kossowska, 2005; Malka et al., 2014). It also shows up for Conscientiousness and Openness from the Big Five, though less consistently (Carney et al., 2008; Mondak, 2010; but see Clifford, Jewell, \& Waggoner, 2015). ${ }^{3}$

The asymmetry likely reflects the 'harder' nature of economic issues, which are not as easy to symbolically connect with dispositional preferences for security, certainty, and structure as issues like abortion, LGBT rights, and immigration (Carmines \& Stimson, 1980; Johnston et al., 2017; Johnston \& Wronski, 2015; Malka \& Soto, 2015). It may also reflect the unique dynamics of opinion formation in the economic sphere, where indices of psychological rigidity and threat sensitivity relate to right-wing economic preferences in opposite directions among those low and high in political engagement (leading the effects to cancel out at the full-sample level; Federico \& Malka, 2018). Finally, other research suggests motives other than those related to needs for security and certainty may matter in the economic domain. For example, Duckitt's (2001) dual-process model of ideology suggests that traits associated with competitiveness, ruthlessness, and tough-mindedness predict right-wing economic preferences (see also Bakker, 2017; Bardeen \& Michel, 2019; Duckitt \& Sibley, 2010; Gerber et al., 2010; Kettle \& Salerno, 2017).

Exposure to elite discourse. Factors governing citizen exposure to elite political discussion also moderate the relationship between psychological variables and ideological preferences. As we have argued, ideologies are socially constructed, and different packages of political positions acquire their symbolic meaning largely through the creative work of political elites operating within the constraints imposed by the history and conditions of a particular society (Noel, 2014; Sniderman \& Bullock, 2004; Federico \& Malka, 2018). Consistent with the idea that society-level discursive and historical factors condition the relationship between dispositions and ideological affinity, research

\footnotetext{
${ }^{3}$ For contrasting perspectives on this asymmetry, see Jost et al. (2017b), Azevedo et al. (2019), and Hennes, Nam, Stern, and Jost (2012).
} 
suggests that variables like a preference for conservation over openness values (Malka et al., 2014, 2019; Piurko, Schwartz, \& Davidov, 2011; Schwartz et al., 2014; Thorisdottir et al. 2007), need for closure (Kossowska \& Van Hiel, 2003), and low Openness to Experience (Roets, Cornelis, \& Van Hiel, 2014) are either unrelated to ideology or associated with stronger preferences for the left in former communist nations, where the left is associated with authoritarianism and perceived as representing an orderly past. Moreover, dispositional needs for security and certainty are more strongly related to ideological conservatism in nations at higher levels of development, where social liberalization has occurred and sociocultural divides over traditional values have emerged and become part of the broader left-right divide (Federico \& Malka, 2018; Malka et al., 2014, 2019; see also Benoit \& Laver, 2006; Lefkoridi, Wanger, \& Willmann, 2014). As noted above, indices of rigidity and threat sensitivity are more strongly related to social attitudes than economic ones, so the grafting of a sociocultural divide onto pre-existing left-right disagreement over economics makes it easier for citizens to sort into different ideological preferences (Johnson et al., 2017; Malka \& Soto, 2015) and partisan identities and voting patterns (Cizmar et al., 2014; Hetherington \& Weiler, 2009) as a function of their basic psychological dispositions.

At the individual level, political engagement also consistently moderates the relationship between psychological dispositions and ideological preferences. All other things being equal, individuals high in political engagement are more likely to attend to elite signals about what different ideological labels mean and what goes with what ideologically (Converse, 1964; Kalmoe, 2020; Kinder \& Kalmoe, 2017). In addition to having a better understanding of what different ideologies mean, those high in political engagement are also more concerned about using their issue stances to signal their broader political allegiances (Kahan, 2015). As a result, they should find it easier to sort into the ideological identities and positions that best match their psychological motives and characteristics (Federico, 2021; Federico \& Malka, 2018). Consistent with this expectation, variables 
Ideology -25

like authoritarianism (Federico et al., 2009, 2011; Johnston et al., 2017), need for closure (Federico \& Goren, 2009; Johnston et al., 2017; see also Federico \& Ekstrom, 2018), low Openness to Experience and high Conscientiousness (Johnston et al., 2017; Osborne \& Sibley, 2012, 2015), and a preference for conservation over openness values (Johnston et al., 2017; Malka et al., 2014, 2019) are all more strongly correlated with ideological conservatism among the highly-engaged. Similar patterns are found for the relationship between variables like authoritarianism and need for closure and political identifications that are linked to ideology, such as Republican partisanship in the United States (Federico \& Reifen-Tagar, 2014; Johnston et al., 2017).

Interestingly, engagement reverses the relationship between needs for security and certainty and the left-right tilt of one's preferences in the economic realm (as noted briefly above). Among those high in engagement, individuals who prefer certainty, security, and structure tend to adopt more right-wing economic attitudes, favoring the free market and less redistribution. Among those low in engagement, the pattern reverses: individuals who prefer certainty, security, and structure tend to adopt more left-wing positions, favoring greater government intervention and redistribution (Johnston et al., 2017; Malka et al., 2014). This pattern has been found for authoritarianism, need for closure, dispositional risk aversion, conservation versus openness values, and the Openness and Conscientiousness dimensions of the Big Five (Federico \& Malka, 2018; Malka \& Soto, 2015).

This reversal reflects different processes of economic-preference formation among those low and high in engagement (Johnston et al., 2017). Among those low in engagement, there is a direct instrumental impact of dispositions, such that those with more rigid, threat-sensitive dispositions favor left-wing economic policies as a form of insurance against the risks and dangers of a market economy. Among those in high in engagement, the impact of 'rigid' preferences for certainty, security, and structure are indirect and more heavily shaped by the abstract ideological meanings that political elites attach to market-oriented versus redistributionist economic positions. 
Ideology -26

Individuals who are more attentive to politics are more likely to gravitate toward the ideological and partisan identities that best match their dispositions and adopt the economic positions that go along with those identities. Thus, engaged citizens who are more psychologically rigid or sensitive to threat sort themselves into right-wing ideological and partisan identities due to a symbolic preference for established ways of doing things and adopt the market-oriented economic positions associated with those identities. In contrast, engaged citizens who are more psychologically flexible and less threatsensitive sort themselves into left-wing ideological and partisan identities due to their greater openness to change and adopt the interventionist positions implied by those identities.

Thus, the reversal found among those high in engagement reflects the meanings that have been typically assigned to different economic doctrines by political elites in many societies, in which support for the free market is seen as shoring up the status quo and support for redistribution and regulation of business is seen as progressive social change (Federico \& Malka, 2018). Consistent with the argument that the symbolic meaning of economic positions in various social contexts is crucial to this process, the reversal effect dissipates in the nations of the former communist bloc (where left-wing positions represent an older, more-traditional way of doing things; Malka et al., 2014), in nations where left-wing economic positions are not consistently tied to socially-liberal positions that individuals high in needs for security and certainty are especially averse to (Malka et al., 2019), and in nations where high levels of redistributive and social welfare spending are seen as morally normative by much of the population (e.g., Nordic and Eastern European nations; Czarnek \& Kossowska, 2019).

Race and ethnicity. Several studies suggest that the typical relationship between dispositional preferences for certainty, security, and structure breaks down among members of racial and ethnic groups that have historically been subject to subordination and oppression. Among members of these groups, the usual tendency for those who score higher on indices of rigidity and threat 
Ideology -27

sensitivity to favor the status quo and adopt conservative positions comes into conflict with a motivation to protect the ingroup's interests (Federico, Feldman, \& Weber, 2021). If one belongs to a racial or ethnic group that is disadvantaged by the status quo, political conservatism may not be as security- and-certainty-enhancing as it is for members of groups that enjoy a dominant position under existing arrangements (though some members of subordinate groups resolve this conflict in favor of system support; see Jost, 2020). Consistent with this expectation, research in the United States finds that authoritarianism (e.g., Dusso, 2017; MacWilliams, 2016), low Openness and high Conscientiousness (Gerber et al., 2011), and numerous other variables indicative of high needs for security and certainty more weakly relate to conservative identities and preferences among Black Americans and Latinos (Johnston et al., 2017).

Type of dispositional measure. Though research suggests that psychological motives and characteristics relate to ideological preferences, this relationship is generally stronger when psychological dispositions are measured using self-reports rather than behavioral measures of psychological functioning. For example, several meta-analyses indicate that self-report personality measures of needs for certainty, security, and structure correlate more strongly with cultural conservatism than behavioral measures of how inflexibly or aversively individuals respond to complex, changing, or threatening stimuli (Van Hiel, Onraet, Crowson, \& Roets, 2016; Van Hiel, Onraet, \& DePauw, 2010). Similarly, while earlier studies suggested that behavioral and physiological measures of threat sensitivity were associated with social conservatism, subsequent studies using larger sample sizes have failed to replicate this result (Bakker, Schumacher, Gothreau, \& Arceneaux, 2020; Fournier, Soroka, and Nir, 2020; Osmundsen et al., 2020; Smith \& Warren, 2020). This asymmetry could reflect the limitations of self-reports as objective measures of how well individuals manage uncertainty, threat, and complex cognitive operations (Bakker et al., 2020). For example, self-report measures related to needs for security and certainty do not correlate with behavioral 
Ideology -28

displays of politically biased reasoning (Guay \& Johnston, 2020) and might be biased, themselves, by political orientation (Bakker, Lelkes, \& Malka, 2020; Ludeke, Tagar, \& Young, 2016). In some instances, self-report measures of this sort contain overtly political content, which exaggerates their correlation with ideology (Conway et al., 2016; Malka et al., 2017). However, the asymmetry may also be due to the lower reliability of behavioral measures (Dang, King, \& Inzlicht, 2020) or the stronger match between the task demands of explicit political attitude measures and self-reports of personality compared to behavioral measures that do not require introspective, conscious judgments (Federico, 2021)

Is the Right Always More Rigid'?

As noted previously, research on the relationship between psychological variables and political ideology is often interpreted as supporting a rigidity-of-the-right model (Malka, Lelkes, \& Holzer, 2017). With respect to the relationship between cultural conservatism and many dispositional measures of rigidity and threat sensitivity, this pattern seems to be well-supported (see Jost, 2009, 2017). At the same time, other research suggests that situational manifestations of rigidity may be more symmetric in their distribution across the ideological spectrum (Harper, 2020; see also Conway et al., 2018; Costello et al., 2021). Specifically, despite well-established ideological asymmetries in dispositions, individuals on both the right and the left may become defensive, rigid, and intolerant when the validity of established political identities or attitudes are threatened or challenged.

This tendency manifests itself in several ways. For example, individuals on both the right and left exhibit motivated reasoning in defense of their worldviews when challenged (Ditto et al., 2019; Guay \& Johnston, 2020; see also Cohen, 2003; Washburn \& Skitka, 2017) — a pattern that often becomes stronger as political knowledge increases (Kahan, 2015). Similarly, individuals at both ends of the left-right dimension avoid perspectives that diverge from their own (Collins, Crawford, \& Brandt, 2017; Frimer, Skitka, \& Motyl, 2017), though some evidence suggests that this tendency is 
somewhat stronger on the right (Nam, Jost, \& Van Bavel, 2013; Rodriguez et al., 2017). Recent efforts to develop self-report measures of authoritarianism on the left also find subsets of individuals on both the left and right poles of the ideological spectrum that exhibit moral absolutism and intolerance of political opponents (Conway et al., 2018; Costello et al., 2021). ${ }^{4}$ Finally, as noted above, relations between feelings of fear and threat and ideology vary considerably depending on the types of threats assessed (Brandt et al., 2020; Hatemi \& McDermott, 2021; Malka et al., 2017).

Evidence of symmetry is also found with respect to cognitive manifestations of rigidity. Compared to centrists, those with extreme views are more likely to overestimate how much knowledge they possess (van Prooijen \& Krouwel, 2019). They also prefer to solve problems in relatively simple ways and experience a greater sense of certainty about the solutions they reach (van Prooijen, Krouwel, \& Emmer, 2018). Individuals whose views are further away from the political center are also more likely to cognitively represent politics in a less-complex fashion (Lammers, Koch, Conway, \& Brandt, 2017; Tetlock, 1984), though other lines of research suggest that it is centrists who show lower levels of political knowledge and complexity in their representations of the political world (e.g., Sidanius, 1988; Treier \& Hillygus, 2009). Finally, individuals on the left and right may be more rigid or flexible in different contexts. For example, though initial evidence suggested that those identified with the right are more cautious and focused on avoiding negative outcomes in exploration tasks (Shook \& Fazio, 2009), this may reverse in contexts that those on the political right are more positively oriented toward (e.g., stock markets; Fiagbenu, Proch, \& Kessler, 2019; Ruisch et al. 2020).

\footnotetext{
${ }^{4}$ As a caveat, however, some recent measures of left-wing authoritarianism correlate more weakly with left-right self-placement than parallel (and older) measures of right-wing authoritarianism (Costello et al., 2021), suggesting that symmetry in authoritarian hostility is not perfect.
} 
Though these results may appear to be at odds with work on left-right differences in dispositional rigidity, symmetry in situational rigidity makes sense in terms of theory and research on the consequences of commitments that are central to a person's identity (Federico, 2021). Politics is largely about important social identities (such as symbolic ideology and partisanship), and human beings are motivated to defend the worth of their identities - regardless of whether that identity has left-wing or right-wing content (Huddy, 2001; Tajfel \& Turner, 1986; see also Campbell et al., 1960; Green, Palmquist, \& Schickler, 2002; Kahan, 2015; Mason, 2018; Van Bavel \& Pereira, 2018). Other political preferences beyond broad identities like ideology and partisanship (e.g., attitudes toward specific political issues) can also become central to the self, and when they do they will also be defended "rigidly" in the face of attack (Krosnick, 1988; Kunda, 1990; Lodge \& Taber, 2013). ${ }^{5}$

Thus, dispositional and situational forms of rigidity may relate to ideological variation in different ways. In this context, it is important to avoid the "jingle-jangle" fallacies, in which constructs with similar names are erroneously assumed to be the same and constructs with different names are incorrectly assumed to be distinct (Block, 1995). Though the dispositional and situational measures we review implicate some form of "rigidity," they reflect different processes with respect to ideological preferences. On one hand, variables related to dispositional rigidity (or unobserved antecedents of those variables; Hatemi \& Verhulst, 2015) may govern sorting into different ideological camps, with those higher (versus lower) in dispositional rigidity sorting into the right (versus the left). On the other hand, variables related to situational rigidity may reflect efforts to defend political commitments that are important to a person's identity, regardless of what end of the left-right spectrum they are on (Brandt \& Crawford, 2020; Federico, 2021). ${ }^{6}$ A critical goal for future

\footnotetext{
${ }^{5}$ Indeed, Zmigrod (2020) argues that rigid, defensive adherence to doctrine and a strong tendency to differentiate between political friends and foes may be constitutive of ideological thinking in general. ${ }^{6}$ Dispositional and situational forms of rigidity may also work together in complex ways. For example, while trait rigidity predicts conservative identifications, it also appears strengthen political
} 
work is to explore the exact interplay between these dispositional and situational processes, with an eye to determining whether observed left-right differences in defensiveness and rigidity are directly attributable to underlying dispositional differences or reflect other processes (Eichmeier \&

Stenhouse, 2019).

\section{Is Ideology Genetically Transmissible?}

Finally, a substantial volume of research has now addressed the possibility that political preferences - like the personality traits that have been found to predict those preferences — have a heritable, genetic component (for a more-detailed review, see Ksiaszkiewicz \& Friesen, 2017; Settle \& Detert, this volume). As we will discuss below when we turn to the social bases of belief-system structure, research in political science has traditionally assumed that ideological orientations are transmitted from one generation to the next via socialization within the family and other social relationships and groups (e.g., Sears \& Brown, 2013). Research on the biological heritability of political preferences challenges this assumption.

Most of this research uses the classic twin design developed by behavioral geneticists, which compares the attitudes of monozygotic twins (who are genetically identical) and dizygotic twins (who share approximately $50 \%$ of their genetic makeup). Given the assumption that twins within both kinds of pairs receive similar environmental influences, this design can be used to obtain estimates of trait variance due to genes and environment (Alford, Funk, \& Hibbing, 2005; Hibbing, Smith, \& Alford, 2014). Studies using this method suggest $40 \%$ to $50 \%$ of the left-right variance in individuals' attitudes can be attributed to additive genetic influences (see Gonzales, Hibbing, \& Smith, in press). Importantly, estimates of attitude heritability pertain to populations, not individuals, and heritability may thus vary across populations subject to different influences (Ksiaszkiewicz \&

identifications on both the right and the left (given that there is residual variance in rigidity among both left and right identifiers; Luttig, 2018; Zmigrod, Rentfrow, \& Robbins, 2020). 
Friesen, 2017). Consistent with this principle, the proportion of variance attributable to genetic effects is larger among those high in political engagement, in recent behavior-genetic studies (Kalmoe \& Johnston, 2021). This suggests that genetic influences on ideological affinity are most likely to actually impact preferences in populations that better understand politics (and the ideological meaning of different political preferences) due to their greater exposure to elite political discourse and other aspects of the political information environment in a particular society.

Though this approach has generated much-needed attention to the possibility that political preferences may be subject to biological as well social influences, aspects of the twin methodology have been criticized, including its assumptions that monozygotic and dizygotic twins experience comparable environments and that genes do not interact with one another or lead individuals to sort into environments with different influences on attitudes (Charney, 2008; Shultziner, 2013). Given that many of the dispositional correlates of ideology reviewed above also appear to be heritable, it is quite possible that observed relationships between personality and ideology may be due to common genetic influences (a pattern referred to as 'pleiotropy' in the genetic literature) rather than a direct causal effect of personality on ideology (Hatemi \& Verhulst, 2015; Osborne \& Sibley, 2020; for a review, see Ksiaszkiewicz \& Friesen, 2017). Further research will be needed to clarify this issue.

\section{A Closer Look at the Social Nature of Ideology}

As our review above suggests, ideological belief systems emerge from the interplay of (1) underlying psychological needs and (2) features of an individual's social and political context. The contextual features that would appear to be most important in this regard are those that provide information about how attitudes and beliefs should be packaged together-information that ultimately emanates from elite messages (Converse, 1964; Zaller, 1992). In many cases, people receive this information and use it when forming or adjusting their political attitudes and beliefs. 
This section addresses why they do so; in other words, the nature of the psychological processes that energize and direct people toward adoption of attitudes and beliefs that are deemed congruent with their ideological commitments. Belief system congruence has often been framed in terms of purely intrapsychic processes having to do with needs for dissonance reduction and cognitive consistency (Heider, 1958; Shafer, 1981). But a key point we wish to make is that the psychological processes underlying ideological coherence are inherently social (Coppock \& Green, 2020; Jost, Ledgerwood, \& Harden, 2008; Rossignac-Milon \& Higgins, 2018; Kahan, 2016;

Kruglanski et al., 2006). Below, we review theory and evidence for relationships with close others, social identifications with salient political groups, and rational deference to trusted elites as sources of belief-system structure.

\section{Relationships with Close Others as a Source of Belief-System Structure}

One important way that the psychological processes underlying belief system coherence are inherently social has to do with motives for bonding, intimacy, and approval from close others. For example, classic research on the inter-generational transmission of political attitudes demonstrated that ideological positions are likely to be transmitted from parents to children, especially to the extent that both parents have similar political beliefs and the family discusses politics frequently (Jennings \& Niemi, 1968). ${ }^{7}$ Meanwhile, there are long-established research traditions addressing the importance of political communication networks and deliberation for political attitudes and beliefs (Berelson, Lazersfeld, \& McPhee, 1954; Huckfeldt, Johnson, \& Sprague, 2004; Mutz, 2006). A review of these literatures is beyond the scope of this chapter, but here we summarize some key

\footnotetext{
${ }^{7}$ Of course these classic findings about putative social transmission must now be considered in the context of evidence that political attitudes have substantial genetically heritable components (e.g., Smith, Alford, Hatemi, Eaves, Funk, \& Hibbing, 2012), especially among individuals high in political sophistication (Kalmoe \& Johnson, 2021).
} 
insights about the roles of motives for interpersonal bonding and closeness in holding together ideological belief systems.

Evidence suggests that desire for closeness with important others can motivate people to align their own social and political opinions more closely with the perceived views of those other individuals (Jost et al., 2008; Stern \& Ondish, 2018). According to shared reality theory (Hardin \& Higgins, 1996), this is done to maintain and solidify important social relationships by establishing a sense of shared reality. Indeed, the long-acknowledged role of consistency motivation in belief system structure seems to have a lot more to do with interpersonal processes than early formulations suggested (Rossignac-Milon and Higgins, 2018). Specifically, the intensity of dissonance-reduction motives seems to depend on whether or not a shared reality with liked others is at stake (eg, Cooper and Fazio, 1984; Cooper, Zanna \& Goethals, 1974; Echterhoff et al., 2005; Newcomb, 1968). Indeed, the enforcement of conformity in views is central to intra-group processes in general, and the construction of realities (including the beliefs representing political reality) are likely "conducted interactively with fellow members of groups to which we belong and that we deem important" (Kruglanski et al., 2006, p. 84).

In fact, if one fully acknowledges the importance of primary social relationships to human flourishing, the potential rationality of seemingly irrational political positions comes into focus. Kahan (2016) notes that for many people there is "expressive rationality" in the adoption of ideologically congruent views that are inaccurate or seemingly contrary to the individual's material self-interest. If the political positions associated with one ideological posture seem to favor policies that would realistically improve one's material situation but the positions of the opposing ideological posture are fervently held by one's close friends and family, which positions is it rational for the individual to adopt? Given that the individual's political behavior will have no detectable impact on 
Ideology -35

policy outcomes (e.g., Downs, 1959) but might well have consequences for their relationships with close others, it could be "rational" to adopt the latter.

When considering how motives to be close to others can facilitate ideological cohesion, social media may play an important role in contemporary contexts. Specifically, much political discussion takes place on social media, and some evidence suggests that this may go hand-in-hand with ideological polarization (Lee, 2016; Lee, Choi, Kim, \& Kim, 2014; though see Boxwell et al., 2012). Bond and Messing (2015) found that people were more likely to be in ideological agreement with those Facebook friends with whom they share close social ties. Barbera et al. (2015) found that Twitter users generally interact with ideologically similar others, and this is especially true of users on the political right. Findings such as these are likely to in part reflect selection of close others and frequent interaction partners on the basis of political homophily. But the desire to reinforce social bonds may lead individuals to develop or amplify ideological agreement with close others on social media (Tufekci, 2018). And even if people interact with politically dissimilar others on social media, there is reason to expect that this would not lead to moderation of political attitudes and could sometimes yield a "backfire effect" resulting in more extreme attitudes (Bail et al., 2018).

The rising polarization in societies such as the United States may also increase the power of bonding and intimacy motives to promote ideological coherence among citizens. As the United States has become affectively polarized, Americans' marriage and dating preferences may be increasingly based on political homophily (Alford, Hatemi, Hibbing, Martin, \& Eaves, 2011; Huber \& Malhotra, 2017; Iyengar, Konitzer, \& Tedin, 2018). There is also some evidence that Americans find those with opposed ideological and partisan views less attractive (Mallinas, Crawford, \& Cole, 2018; Nicholson, Coe, Emory, \& Song, 2016) or at least that they are motivated to claim that they do (Yair \& Huber, 2020). Even when individuals do not select partners on the basis of ideological similarity per se, they may do so on the basis of other characteristics that are correlated with politics, 
leading to more highly correlated ideological views between partners (Klofstad, McDermott, \& Hatemi, 2013). Thus, if fewer Americans are romantically involved with ideologically dissimilar others, there is less opportunity for bonding motives to propel departures from ideologically constrained belief systems.

The likelihood of close others reinforcing existing political predispositions also increases to the extent that Americans have sorted into politically congenial areas. How much Americans are geographically segregating on the basis of political preferences is currently a matter of debate, though (Bishop \& Cushing, 2008; Mummolo \& Nall, 2017). Recently, Martin and Webster (2020) reported evidence that Americans are sorting based on non-political lifestyle factors (e.g., population density) that happen to correlate with political preferences, but only to a small extent. In fact, as the authors note, one would expect far less geographical polarization than what is present in the United States, given the frequency with which Americans move and the modest extent to which politics and related lifestyle preferences influence their moving decisions. Martin and Webster (2020) contend that the most likely explanation for this is that citizens come to adopt the political preferences that are represented in their area, consistent with the general view that geography has a strong influence on political cognition (Enos, 2017).

Even for Americans who do have politically diverse social networks, there are forces that work against any tendency these networks might have to promote ideologically cross-cutting belief systems. For example, motives for harmonious interpersonal interaction often inhibit people from expressing political disagreement (Gerber, Huber, Doherty, \& Dowling, 2012; Noelle-Neumann, 1974), which can have the consequence of enhancing the homogeneity of political discussion networks (Cowan \& Baldassari, 2018). In this regard, Mutz (2006) noted an intrinsic tension between promoting a politically active citizenry and one that is interpersonally exposed to attitudechallenging communication. To the extent that people have politically diverse discussion networks, 
she found, they were less likely to engage actively with politics; rather, politically homogenous discussion networks nurtured more political activism.

Social Identification with Political Groups as a Source of Belief-System Structure

Social identity refers to emotionally important self-categorization as a member of a social group (Tajfel \& Turner, 1986). It is probably the most frequently invoked concept for integrating societal and individual psychological levels of analysis in the social sciences (Brewer, 2001; Hogg, Terry, \& White, 1995). Because the study of ideological belief systems inherently involves such integration, the importance of social identity for such belief systems is often recognized, either directly or indirectly (Haas, Jones, \& Fazio, 2019; Huddy \& Bankert, 2017; Layman \& Carsey, 2002; Malka \& Lelkes, 2010).

The prior section addressed the roles of interpersonal bonds in holding ideological belief systems together, and in many cases these bonds are held with others with whom one shares a larger group-based identity. But there is an important distinction between groups that are mainly based on interpersonal bonds and those that are mainly based on a common social identification (Prentice, Miller \& Lightdale, 1994). The nature of the larger groups people socially identify with vary a great deal, and they include ethnic groups, social classes, genders, nationalities, and religions. Many are explicitly political, including ideological groups (e.g., conservatives), groups defined by position on a salient issue (e.g., Remainers in the context of the Brexit debate in the UK), social movements (e.g., Black Lives Matter), and, perhaps most prominently, political parties. These types of social identities structure political thinking and motivate people to form and represent themselves as possessing attitudes and beliefs that are consistent with the social identity (Federico \& Malka, 2018; Johnston et al., 2017; Kahan, 2015).

A comprehensive account of how social identity (in all its various forms) relates to ideology is beyond the scope of this chapter. Instead, we narrow our focus in two ways. First, we zero in 
specifically on the role of social identity in holding different political idea-elements together. Second, because many forms of social identity (see Brewer, 2001; Deaux, 1996; Thoits \& Virshup, 1997) are likely to exert their influence on political attitudes via their incorporation into explicitly political social identities, we focus only on the latter. In short, we focus on the role of explicitly political identities in pulling various political beliefs, attitudes, and perceptions into ideological alignment. This story, of course, starts with party identification.

Partisan identity. It makes sense to regard party identity as the key attribute that pulls diverse political idea elements into ideological packages. Parties are indispensable to democratic functioning, as they are the coalitions that channel individual preferences into organized collective action aimed at gaining power and realizing policy outcomes. When a citizen identifies with a party, they are psychologically aligning themself with a coalition whose purpose is to harness the energy and desires of various groups to the goal of gaining political power. Indeed, many other social identities (such as those based on class or ethnic group) can exert their influence on political attitudes via identification with a party that is viewed as representing the interests and values of these social groups.

Partisan identity has, and still does, function as a "perceptual screen" that guides political thinking and underlies attitude constraint (Campbell et al., 1960). For example, panel data suggest that people adjust their political attitudes to match their party identities in the US (Layman \& Carsey, 2002; 2006) and elsewhere (Harteveld, Kokkonen, \& Dahlberg, 2017; Slothuus, 2015; Slothuus \& Bisgaard, 2020). Partisan identity also motivates individuals to rationalize their party's stances by adopting beliefs that justify those stances (Bisgaard, 2019; Lauderdale, 2016; Tilley \& Hobolt, 2011). Moreover, experimental data are consistent with citizens adopting the attitudes that political messaging cues indicate to be party-consistent (Arceneaux \& Vander Wielen, 2017; Bisgaard \& Slothus, 2018; Brader \& Tucker, 2012; Druckman, Peterson, \& Slothuus, 2013; Merolla, Stephenson, \& Zechmeister, 2016). Thus, to the extent that opposed parties in a given political context offer 
ideologically distinct programs, all of these social motives associated with partisanship should promote more ideologically-cohesive views among partisans (Abramowitz, 2010; Levendusky, 2009).

The most common explanations for the power of partisanship to structure political thinking invoke partisan motivated reasoning, or reasoning that is biased toward reaching party-congenial conclusions (Bakker, Lelkes, \& Malka, 2020; Leeper \& Slothuus, 2013; Peterson et al, 2013). This brings up a key distinction between two explanations for how partisan identity functions: instrumental partisanship and expressive partisanship (Huddy, Mason \& Aaroe, 2015; Huddy, Bankert, \& Davies, 2018; see Fiorina, 1976; Hamlin \& Jennings, 2018). According to the instrumental explanation, party identity reflects a running tally of the relative merits of the parties, which is updated as individuals acquire new information. This view emphasizes motives for accuracy in the processing of political information. According to the expressive explanation, party identity is a social identity that varies in strength across individuals. To the degree that it is strong, it motivates people to engage in partyconsistent political cognition, attitude formation, and activity. This view emphasizes 'consistency' or identity-expressive motivation.

Huddy and colleagues have demonstrated the utility of the expressive view of partisanship in the United States (Huddy et al., 2017) and in multi-party European democracies (Huddy, Bankert, \& Davies, 2018). This perspective suggests that party identification leads people to adopt party-aligned attitudes because they gain expressive satisfaction from doing so. In this way, expressive motivation to adopt party-consistent attitudes may be one source of ideological constraint in systems where competing parties offer ideologically distinct programs (Campbell et al., 1960; Converse, 1964). Others, however, note that people might gain expressive utility merely from reporting party-aligned views in a survey, while not actually holding these views with sincerity (Bullock et al 2015; Bullock \& Lenz, 2019). However, Malka and Adelman (under review) note that evidence for insincere responding on matters of strong partisan valence is quite limited, and that if expressive motivation is 
strong enough to make people misrepresent their views in surveys then it is likely strong enough to influence their real-world political behavior. ${ }^{8}$

Other types of political social identity. It is for good reason that party identity is the main focus in explanations of how political identities structure political thinking and guide political behavior. A major part of partisan identity's power comes from the fact that it can subsume other identities that influence political attitudes, beliefs, and perceptions (e.g., Mason, 2018). Because parties are coalitions of groups, other social identities get baked into the partisan cake. Nonetheless, recent work underscores how shifting political contexts can change the independent importance of other types of political identities. Here we briefly discuss three other political identities that have potential to shape the content and structure of belief systems. These are identification with a revered leader, identification with salient and branded issue stances, and identification with an ideological label. When people talk about partisan influences on political behavior, the term 'partisan' is sometimes used broadly to reflect allegiance to something that is not the party per se but is strongly associated with it. A key example here is a revered leader who belongs to a particular party. Much research has addressed the importance of relationships between political leaders and citizens (Blondel, 1987; Caprara \& Zimbardo, 2004; Kunst, Dovidio, \& Thomsen, 2019). Social identifications with groups, such as political parties, can result in strong feelings of relational identification with key leaders (Steffens, Haslam, \& Reicher, 2014). Moreover, according to "transformational" approaches to leadership (Weber 1921), when leaders possess sufficient charisma they "not only direct, but actively transform, their followers' attitudes and behavior" (Reicher, Haslam, and Hopkins, 2005). To Reicher et al. (2005), those who become influential leaders within a group organized around a social identity are those who "are in a position to supply information

\footnotetext{
${ }^{8}$ Other work, described later, focuses on the roles of accuracy motives and rational updating in partisan cue receptivity.
} 
Ideology -41

about the category definition." In this way, identification with a political leader that offers a clear ideological package of positions, above and beyond identification with an associated party, has the potential to pull attitudes and beliefs into ideological alignment.

Space limitations preclude a widely inclusive review of this literature. But it will serve our purpose to briefly describe one example: in the United States, many Republicans now identify more with Donald Trump than with the Republican Party itself (Page \& Elbeshbishi, 2021; Rummler, 2021). This matters, as it impacts elite incentives for whom to align with in a conflict between the revered leader and other elements of the party establishment. The electoral incentives are quite clear, as the party (as of this writing) has adjusted by aligning further with Trump and weeding out antiTrump elements. But Trump and his followers' identification with him, we would argue, are altering the definition and content of conservative ideology itself (Drutman, 2020; Hopkins \& Noel, 2021; Lewis, 2019). That is, social identification with Trump seems to be quite important for pulling ideaelements into an ideology and binding them together with this identity so that they are difficult to change. Kunst et al. (2019), for example, found that, among white Republicans, 'identity fusion'defined as a deep-seated feeling of oneness with a group or individual — with Trump was a far stronger and more reliable predictor of support for persecution of disfavored ethnic groups and political violence than identity fusion with the Republican Party was. Because of identification with Trump, these attitudes might come to figure more prominently in the American 'conservative' package while (for example) support of democracy-promoting wars overseas might become less central to that package. Thus, identification with a revered leader can structure ideological belief systems independently of party identity.

Other "partisan" influences on political behavior have more to do with a salient, branded issue stance or a movement. Consider the "Leave" versus "Remain" divide over Brexit that began to consume British politics in 2015. Hobolt and her colleagues note the traditional view of affective 
Ideology -42

polarization as pertaining to animosity directed at members of the opposing party, but showed that identification with a stance on Brexit, which cut across party lines, generated affective polarization and outgroup prejudice that were at least as strong as those associated with partisanship (Hobolt, Leeper, \& Tilley, 2020; Sorace \& Hobolt, 2020; see also Evans and Schaffner, 2019). A similar phenomenon occurred with the Tea Party movement in American politics in 2010. Williamson, Skocpol, and Coggin (2011) noted how this movement provided a new source of identity for many Republicans that was "untethered from recent GOP baggage and policy specifics" and was built around a belief package focused on racially infused grievance against government assistance to "undeserving" elements in American society. This identity, while associated with the Republican Party, went beyond party in the broad sense and helped shift the ideological content of American conservatism. In fact, it served to distinguish a subset of Republican voters from the party establishment, energized the defeat of Republican establishment candidates, and presaged Trump's hostile takeover of the Republican Party (e.g., Parker \& Barreto, 2013). Thus, identification with a salient issue stance or an associated movement can impact belief systems independently of party identity.

A third example pertains to direct symbolic identification with an ideological label. Right versus left, or conservative versus liberal, is a common way of discussing and interpreting political differences in many parts of the world (as noted above). Within the United States, ideological selflabeling_ or symbolic ideology, to use the term discussed earlier (Ellis \& Stimson, 2012)—does seem to promote adoption of identity-consistent attitudes (Devine, 2015; Malka and Lelkes, 2010; Mason, 2018). Knutson (1995) demonstrated the "absorptive power" of left versus right identification in Western European countries, showing that this identification had retained its stable core meaning in the economic domain while absorbing wider cultural meanings over time. Knutson's (1995) analysis suggests that ideological identification can be a force that pulls idea- 
Ideology -43

elements into an ideology in a shifting political information environment, as "new meanings of left and right are added to the old meanings." Of course, as we have seen, symbolic identification with an ideological label is not all-powerful: many individuals who identify with a specific ideological category do not adopt the issue positions that follow from it (especially with regard to right-wing economic positions among self-identified conservatives; see Ellis \& Stimson, 2012). Thus, identification with an ideological label can to some extent structure broader belief systems independently of partisan identity.

Finally, in a polarized environment where different social and political identities increasingly align along a single dimension of political conflict, it might make the most sense to speak in terms of "mega-identities" that structure ideological belief systems (Finkel et al., 2020; Mason, 2018). As we discuss later, many scholars express concern that the tendency to interpret all societal tensions and divisions in terms of conflict between overarching political identities is a danger to democracy in the United States (Drutman, 2020; McCoy \& Simonovits, 2020) and other countries (McCoy, Rahman, \& Somer, 2018; Slovik, 2019). Although these mega-identities encompass more than partisanshipthey also incorporate ideological labels, reverence for prominent leaders, salient identity-conferring issue stances, and identification with social movements - the nature of parties is that they come to represent sides in these overlapping societal divisions, thus absorbing other sources of societal conflict into partisan conflict. Mason and Wronski (2018), for example, show that party identity in the United States, especially among Republicans, now represents a more broadly aligned set of social group memberships which enhances its power to structure political thinking and define the content of liberalism and conservatism.

\section{Deference to Trusted Elites as a Source of Ideological Constraint}

In the previous section we noted how the desire to express a valued political identity — most often partisanship_ — can lead people to adopt attitudes and beliefs that match that identity, resulting 
in greater ideological cohesion when competing identities are ideologically-differentiated. But while it is clear that many people adjust their attitudes to match those of their political "side" (e.g., their party, a revered leader, etc.), discerning the motives for doing so is a complicated matter. The desire to express one's identity may not be the only operative factor. In this vein, a venerable tradition within political science depicts partisan cue-taking about issues as a form of effort-saving political rationality rooted in social trust (Lupia \& McCubbins, 1998; Popkin, 1994; Sniderman, Tetlock, \& Brody, 1991). The key idea here is that if one trusts a set of political elites to hold reasonable or moral political stances (and distrusts the opposing set of elites), then it is rational to defer to these elites (or avoid the positions of the opposing elites) when forming attitudes and making political choices.

Tappin, Pennycook, and Rand (2020) recently addressed this issue. The type of design most often used to examine expressive, identity-based influences on belief systems is the "party cues" design, where participants are provided with information that a particular issue position is endorsed by their party or an out-party. Considering this design, Tappin and his colleagues (2020) note the following:

...party cues signify endorsement by a source that is either perceived as trustworthy and aligned with one's interests (same party cue), or as untrustworthy and opposed to one's interests (opposition party cue). Thus, the information treatment alters perceived source trustworthiness. (p. 84)

Manipulations that provide party cues about an issue in an effort to causally identify the effect of expressive motives often violate the excludability assumption-i.e., that the manipulation only alters the expressive reward associated with adopting one stance or another. Rather, they also alter whether one stance or another is thought to be most consistent with prior beliefs. That said, it is important to note these prior beliefs still pertain to social identity, as they are about trust or distrust of particular groups of elites on the basis of identity match versus mismatch. Thus, the effect demonstrated in cue experiments is social in nature regardless of whether expressive motives or 
rational reliance on trusted elites is at work. ${ }^{9}$ Either path can socially facilitate the formation of ideologically-consistent preferences to the extent that parties and their leaders offer ideologicallydistinct sets of policy options.

To the degree that ideological constraint is rooted in deference to knowledgeable elites that one trusts on the basis of prior opinions, this suggests a normatively welcome role of accuracy motivation in the formation of ideological belief systems, even if reliance on trusted elites is heuristic in nature (Chaiken \& Ledgerwood, 2011). In truth, it is likely that accuracy motives (i.e., those aimed at holding correct opinions) and consistency motives (i.e., those aimed at reaching identityconsistent conclusions) both impact political reasoning to some degree (Lavine, Johnston, \& Steenbergen, 2012; Groenendkyk, 2013; Groenendyk \& Krupnikov, 2021). Groenendyk (2018), for example, has argued that the present context of American polarization has heightened both the motive to adopt and justify identity-consistent attitudes and the motive to be open-minded and rational in the adoption of political attitudes. These motives conflict when one is presented with unfavorable information about one's own party, in which case accuracy motivation would favor accepting this information while consistency motivation would favor rejecting it. The solution, according to Groenendyk (2018), is to accept the unfavorable information about one's own party and to then further derogate the opposing party in one's mind in a "lesser-of-two-evils" political justification strategy. In the context of parties that are ideologically sorted at the elite level, this suggests that out-party elites might be more of a guide to what is ideologically inappropriate than same-party elites are to what is ideologically appropriate (e.g., Nicholson, 2012)

\footnotetext{
${ }^{9}$ Guay and Johnston (2020) designed experiments to overcome this confound and still found a substantial amount of politically motivated reasoning, andt approximately equal levels of this among conservative and liberal identifiers (see also Ditto et al., 2019).
} 
Ideology -46

\section{Reversing the Causal Arrow: Political Commitments as Influences on Non-political Identities}

Traditionally, studies of traits, social identities, and political attitudes have modelled the latter as the dependent variable and traits and social identities as independent variables. This approach implies a clean delineation between individual differences in non-political constructs and individual differences in political constructs_ and it assumes uni-directional causal influence of the former on the latter. Although this approach simplifies theorizing about ideology, it may fail to capture the nature of political worldviews in all circumstances. In this section, we have emphasized that interpersonal experiences, social identities, and orientations toward the social world are what promote the binding of idea-elements into ideological belief systems. The power of social motives to do this comes from the fact that political beliefs and attitudes are viewed as compatible with or inherently part of non-political identities and self-perceptions. However, this logic implies that non-political identities and selfperceptions may themselves be adopted as a result of prior political commitments. In other words, it might make sense to conceptualize and operationalize ideological belief systems in a more encompassing way that includes both political and ostensibly non-political elements that are drawn together into alignment. Emerging work-which we review in this section-highlights the potential advantages of this approach.

For example, consider religiosity. The usual approach in political psychology is to assume that individual differences in religiosity exert a constraining influence on ideological affinity and other political preferences (Layman, 2001; Malka, 2013). Correlations between religiosity and conservative political attitudes are therefore assumed to reflect a unidirectional causal influence of the former on the latter. Patrikios (2008), however, used panel data from the United States to demonstrate that political commitments (party identification in particular) influence religiosity. Republican identity was associated with increased religiosity over time while Democratic identification was associated with the opposite. Margolis (2018a; 2018b) expanded on this by 
demonstrating that partisans with young children at home, who face a decision about whether and how religion should factor into their child-rearing, are particularly likely to adjust their level of religiosity on the basis of their partisanship. She concluded that "the strong association between religiosity and partisanship comes about, in part, because partisans adopt their party's religious stances as their own" (Margolis, 2018a, p. 30).

What about other demographic identities? American partisan coalitions are to an important degree sorted on the basis of identities having to do with ethnicity, religion, sexual orientation, and class. Furthermore, many politically-engaged people have an exaggerated view of how sorted the parties are with respect to these identities (Ahler \& Sood, 2018). Because demographic identities correspond with group memberships that are costly or difficult to change, it is usually assumed that they are fixed attributes whose relationships with political attitudes exclusively reflect their causal influence on the latter. However, Egan (2020) recently noted that demographic identities can shift over time, both because they represent a subjective attachment to a group (as distinct from an objective group membership) and because people's personal attributes sometimes position them at the boundaries of the group memberships that correspond with an identity. This raises the possibility that political commitments_-including ideological ones_-exert causal influence on the claiming of demographic identities. Indeed, using panel data from the United States, Egan (2020) found that small but significant segments of the American public change their ethnic, class, religious, and sexual identities to better match the prototypes of their partisan and ideological groups.

Finally, similar processes may be at work with respect to self-reported personality traits and self-perceptions. Due to their relatively strong rank-order stability in adulthood and their substantial heritable component, traits are often assumed to be causes, not consequences, of political commitments (cf. Hatemi \& Verhulst, 2015). But it is possible that political commitments exert some causal influence on self-reported personality traits (Bakker, Lelkes, \& Malka, in press). This 
might in part be because these commitments lead people to adopt behavioral and experiential patterns that are stereotypical of their ideological or partisan in-group, or because they lead people to perceive themselves as similar personality-wise to the prototypical member of their political ingroup. For example, Ludeke and his colleagues (2016) found evidence that people "overclaim" traits that characterize their ideological groups relative to the trait levels that would be expected on the basis of non-self-report indicators (e.g., peer reports). Similarly, some longitudinal evidence suggests that ideological and other preferences exert causal influence on personality traits, although these effects are small (Bakker et al., in press; Boston et al., 2018; Luttig, 2021; cf. Osborne \& Sibley, 2020). Finally, Bakker et al. (in press) found that individuals report personality traits that are slightly more congruent with their previously assessed political attitudes when politics is primed. All of this suggests that people are at least motivated to perceive their personalities as consistent with the prototypes of their ideological groups.

In sum, recent evidence suggests that the nature of the causal relationship between background characteristics and ideological affinity may be more complex than researchers have sometimes assumed. Ideology and other political identities may influence demographic identities and self-reported psychological dispositions, as well as being influenced by them. To be sure, the more complicated picture painted by this new evidence does not (in our opinion) imply that researchers should abandon the effort to identify causal antecedents of ideology. However, it does suggest that researchers may need to better contextualize effects of demographics and personality on ideology as part of a broader, multidirectional network of causal effects.

\section{Implications for Polarization and Democratic Functioning}

Scholars have long debated the precise importance of public opinion for democracy (Claassan, 2019; Dahl, 1971; Fails \& Pierce, 2010; Lipset, 1959; Welzel \& Inglehart, 2008). But 
public opinion influences the incentives of political elites to degrade or preserve democratic institutions and communicates the extent to which there exists support for mass action to degrade democracy (Malka \& Costello, under review; Graham \& Svolik, 2020; Svolik, 2020; Sullivan, Piereson, and Marcus, 1971). Many of the insights about the nature of ideology that we have described in this chapter have implications for attitudes towards democracy and actions that degrade democracy. In this final substantive section of our chapter, we review them.

First, some of these insights bear on the long-running question of whether certain ideological groups are more likely than others to support democracy-eroding efforts. A classic view from psychology is that individuals oriented toward the right are the most anti-democratic (Adorno et al., 1950; Nilsson \& Jost, 2020). However, many classical measures tapping anti-democratic sentiment are optimized for detecting right-wing forms of illiberalism (Malka et al., 2017), and changes in measurement strategies can be undertaken to assess individual differences in authoritarianism-related constructs that apply specifically to the left (Costello et al., 2021; Conway et al., 2016). Furthermore, intolerance might have more to do with rigid ideological commitment in general than with a broad-based right-wing or left-wing orientation (Crawford \& Pilanski, 2014; Brandt, Reyna, Chambers, Crawford, \& Wetherell, 2014; Zmigrod, 2020).

That being said, recent work has addressed whether right- versus left-wing preferences relate to preferences for authoritarian governance. In this work, support for authoritarian governance is measured in a narrow way that focuses strictly on lack of commitment to democracy and support for degrading democratic institutions and norms. Malka, Lelkes, Bakker, \& Spivack (2020) addressed this question using data from 14 consolidated Western democracies and two distinct survey projects. Cultural conservatism consistently predicted openness to authoritarian governance, across all countries and with effect sizes typically exceeding those for college education, political engagement, and other oft-noted predictors of democracy attitudes. This finding was replicated in a pre-registered 
study with a large demographically representative American internet sample in September 2020 (Malka \& Costello, under review). This is consistent with theoretical perspectives linking ethnic antipathy (Miller \& Davis, 2020) and opposition to societal liberalization (e.g., Welzel, 2007) to antidemocratic views. It is also consistent with the possibility that underlying genetic factors and/or needs for security and certainty may bind together cultural traditionalism and authoritarianism (e.g., Ludeke, Johnson, \& Bouchard, 2013).

However, desires for certainty and security relate to left-wing attitudes in some domains for substantial subsets of citizens, as noted previously (Johnston et al., 2017; Malka et al., 2014), and needs for security and certainty often give rise to a "protection-based" attitude configuration representing a combination of cultural traditionalism and redistributive economics (Malka et al., 2019). This suggests that a combination of right-wing cultural preferences and left-wing economic preferences might be uniquely associated with a high level of anti-democratic sentiment. Indeed, Drutman et al. (2017) found this in American data, and this finding replicated in all of the Englishspeaking countries (Australia, Britain, Canada, New Zealand, and the United States) in the aforementioned study using World Values Survey and Latin American Public Opinion Project data (Malka et al., 2020) as well as the aforementioned American internet sample from 2020 (Malka \& Costello, under review). Increasingly, evidence suggests that within the United States and other English-speaking countries, there is a something about the protection-based belief-system configuration that coheres with anti-democratic sentiment (e.g., Carmines, Ensley, \& Wagner, 2016; Lefkofridi \& Michel, 2017; Lipset, 1959).

A second way in which insights about ideology relate to public opinion regarding democracy has to do with the social aspects of ideological constraint. As we have argued, the extent to which ideological conformity is enforced in social and interpersonal contexts is often underappreciated. The interpersonal importance of toeing the ideological line may combine with the fact that an 
Ideology -51

individual's political behavior usually has no meaningful instrumental consequences in the broader world to make political behavior mainly about relationship maintenance and identity expression (Hamlin \& Jennings, 2011; Kahan, 2016; Robbets \& Matthews, 2016). If shared reality with close others is at stake, then there are serious obstacles to ideologically committed people defying antidemocratic actions undertaken by ideologically-aligned elites and peers.

In the United States, surveys reveal worrying growth in anti-democratic sentiment (Drutman et al., 2019; Malka \& Lelkes, 2017). These concerns are intimately tied to mounting affective polarization and the growth of social networks that are increasingly homogenous in political terms (Drutman et al., 2019; Drutman, 2020; Graham \& Slovik, 2020; Malka \& Costello, 2021; McCoy \& Simonovits, 2020). A common explanation for this increase in anti-democratic sentiment is that viewing the other side as existentially threatening can lead citizens to prioritize keeping opponents out of power over a commitment to the democratic process (Graham \& Svolik, 2020; Svolik, 2019). But, as Malka and Costello (under review) note, it is also important to recognize how the absorptive power of ideologically-relevant identities to incorporate a range of elite-cued beliefs into an ideological bundle in a particular time and place (Knutson, 1995; Malka and Lelkes, 2010; Lewis, 2019) and to propel rationalization strategies that justify these beliefs (Lauderdale, 2016; Taber \& Lodge, 2006), can promote support for anti-democratic actions. In this vein, research indicates that a considerable number of citizens simultaneously support democracy in the abstract and favor authoritarian actions under-taken by their side (Drutman et al., 2019; Inglehart, 2003). This asymmetry suggests that the beliefs incorporated into ideologically-relevant identities may allow individuals to believe that effectively authoritarian actions by one's side actually serve to "protect" democracy (Malka \& Costello, under review).

Acknowledgement of the social and interpersonal factors behind the coherence of ideological belief systems highlights the challenges faced by efforts to reduce partisan animosity and 
Ideology -52

potential threats to democracy via messages and interventions (e.g., Feinberg and Willer, 2013; Lees

\& Cikara, 2020; Levendusky, 2018). First, if adoption of identity-consistent beliefs serves the goal of fitting in and getting along in one's social surroundings, then the effects of a countervailing message are unlikely to survive the recipient's return to their normal social surroundings and its associated messages and incentives. Rather, the attitude or belief promoted by the message would have to be continually socially reinforced, and this would require a change in incentives, and therefore messaging, from trusted political elites. Second, if people are motivated to identify with attributes that are prototypical of their ideological group, this should over time enhance perceptions that political opponents are fundamentally different, alien, and threatening (Bakker et al., in press; Egan, 2021; Margolis, 2018b; Mason \& Wronski, 2018). Third, if trusted elites present self-serving authoritarian actions as actually serving to protect democracy, then this belief will likely be absorbed into broader ideological postures, particularly for culturally conservative groups (Malka \& Costello, under review). As long as trusted ideological and partisan elites have political incentives to be divisive and to rationalize anti-democratic actions, counter-vailing efforts to reduce polarization and anti-democratic sentiment through messaging face an uphill battle.

\section{Conclusion}

In his chapter on ideology from the previous edition of this Handbook, Feldman (2013) emphasized the complexity involved in drawing connections between the character of ideology at the elite level and that at the mass level. Any notion of what "ideology" is at the mass level, Feldman observed, must be reconciled with findings suggesting multiple attitude dimensions that are not ideologically aligned for many people, low levels of attitude constraint, and largely-unstable issue preferences. Indeed, if one defines ideology as a consistent, stable network of related beliefs and attitudes about the social and political world, Converse's (1964) conclusion that most of the public is 
"innocent of ideology" (while extreme in tone) would appear to remain more accurate than inaccurate (Kinder \& Kalmoe, 2017).

That being said, among the most reliable findings in political psychology is that those segments of the population who are politically engaged are more likely to hold temporally stable political attitudes that are consistently aligned along the left-right dimension (Baldassari \& Gelman, 2007; Malka et al., 2019; Zaller, 1992). Moreover, these individuals are more likely to display traits, values, and identities that are aligned with these political attitudes. If ideology represents a system of interconnected political attitudes and beliefs_-even if they are not necessarily connected as a result of consistent application of abstract ideological principles — then an important highly-active segment of the population is in fact functionally ideological.

In this chapter we have reviewed findings about the nature and origins of ideology among ordinary citizens and the social nature of the motives underlying the coherence of ideological belief systems. We leave the reader with two key take-home points that we believe can be helpful in guiding research on ideology. The first, which we emphasized in a previous review (Federico \& Malka, 2018), is that links between underlying psychological attributes and ideological preferences are usefully viewed as varying along a continuum (Johnston, Lavine, \& Federico, 2017; Malka \& Soto, 2015). At one end of this continuum are "menu-independent" relationships that are organic and functional, meaning the political preference directly helps satisfy the underlying psychological needs represented by the attribute. At the other end of this continuum are "menu-dependent" relationships that are indirectly present only because the relevant political attitudes happen to be discursively packaged with other attitudes that organically relate to the psychological attribute. Distinguishing such menu-independent and menu-dependent relationships between psychological attributes and political attitudes is important for gaining a realistic understanding of how basic psychological orientations and processes attract people to specific political coalitions and their 
associated ideologies. It is also important for integrating perspectives that emphasize the durable, psychologically-rooted features of ideology (e.g., Duckitt \& Sibley, 2009; Jost et al., 2003, 2009) with perspectives emphasizing the flexible, socially-constructed aspects of ideology (e.g., Hopkins \& Noel, 2021; Lewis, 2019; Noel, 2014).

Our second take-home point is that the social motives that facilitate the coherence of ideological belief systems have an under-appreciated implication. The ideologically-congruent attitudes, beliefs, and self-perceptions that people are motivated to adopt need not be limited to the political realm. Indeed, many attributes thought to exert unidirectional causal influence on political attitudes—such as religiosity, demographically-rooted social identities, and personality traits—might also be pulled into alignment with a political orientation (Bakker et al., 2021; Egan, 2020; Ludeke et al., 2016; Margolis, 2018b; Patrikios, 2008; Sidanius, Kteily, Sheehy-Skeffington, Ho, Sibley, \& Duriez, 2013). In other words, the social and psychological forces that bind political attitudes into ideological belief systems might simultaneously pull non-political identities, self-perceptions, and even behavioral propensities into their event horizon when those ostensibly non-political characteristics are deemed ideologically congruent in a polarized context. This matters because it can infuse political conflict with greater cultural and personal meaning and increase animosity against political outgroups. The clean delineation of psychological attributes as causes and ideological belief systems as effects may thus be unwarranted. 


\section{References}

Abelson, R. P., Aronson, E. E., McGuire, W. J., Newcomb, T. M., Rosenberg, M. J., \& Tannenbaum, P. H. (1968). Theories of cognitive consistency: A sourcebook. Rand-McNally: Chicago.

Abramowitz, A. I. (2010). The disappearing center: Engaged citizens, polarization, and American democracy. New Haven, CT: Yale University Press.

Achen, C. H. (1975). Mass political attitudes and the survey response. American Political Science Review, 69, 1218-1223.

Adorno, T. W., Frenkel-Brunswik, E., Levinson, D. J., \& Sanford, R. N. (1950). The authoritarian personality. New York, NY: Harper.

Ahler, D. J., \& Sood, G. (2018). The parties in our heads: Misperceptions about party composition and their consequences. The Journal of Politics, 80(3), 964-981.

Alford, J. R., Hatemi, P. K., Hibbing, J. R., Martin, N. G., \& Eaves, L. J. (2011). The politics of mate choice. The Journal of Politics, 73(2), 362-379. doi:10.1017/S0022381611000016

Allport, G. W. (1954). The nature of prejudice. Cambridge, MA: Addison-Wesley.

Altemeyer, B. (1998). The other "authoritarian personality". Advances in Experimental Social Psychology, 30. 47-92.

Arceneaux, K., \& Vander Wielen, R. J. (2017). Taming intuition: How reflection minimizes partisan reasoning and promotes democratic accountability. New York: Cambridge University Press.

Azevedo, F., Jost, J. T., Rothmund, T., \& Sterling, J. (2019). Neoliberal ideology and the justification of inequality in capitalist societies: Why social and economic dimensions of ideology are intertwined. Journal of Social Issues, 75, 49-88.

Bail, C. A., Argyle, L. P., Brown, T. W., Bumpus, J. P., Chen, H., Hunzaker, M. F., ... \& Volfovsky, 
A. (2018). Exposure to opposing views on social media can increase political polarization. Proceedings of the National Academy of Sciences, 115(37), 9216-9221.

Bakker, B. N. (2017). Personality traits, income, and economic ideology. Political Psychology, 38(6), 1025-1041. https://doi.org/10.1111/pops.12349

Bakker, B.N., Lelkes, Y., \& Malka, A. (in press). Reconsidering the Relationship Between SelfReported Personality Traits and Political Preferences. American Political Science Review.

Bakker, B. N., Lelkes, Y., \& Malka A. (2020). Understanding partisan cue receptivity: Tests of predictions from the bounded rationality and expressive utility perspectives. Journal of Politics, 82, 1061-1077

Bakker, B. N., Schumacher, G., Gothreau, C., \& Arceneaux, K. (2020). Conservatives and liberals have similar physiological responses to threat. Nature Human Behavior.

Baldassari, D., \& Gelman, A. (2008). Partisans without constraint: Political polarization and trends in American public opinion. American Journal of Sociology, 114, 408-446.

Baldassarri, D., \& Goldberg, A. (2014). Neither Ideologues nor Agnostics: Alternative Voters' Belief System in an Age of Partisan Politics. American Journal of Sociology, 120(1), 45-95. doi:10.1086/676042

Barberá, P., Jost, J. T., Nagler, J., Tucker, J. A., \& Bonneau, R. (2015). Tweeting from left to right: Is online political communication more than an echo chamber. Psychological science, 26(10), 1531 1542.

Bardeen, J. R., \& Michel, J. S. (2019). Associations among dimensions of political ideology and Dark Tetrad personality features. Journal of Social and Personality Psychology, 7, 290-309.

Benoit, K., \& Laver, M. (2006). Party policy in modern democracies. London: Routledge.

Bishop, B., \& Cushing, R. (2008). The big sort: migration, community, and politics in the United States of 'those people.'. Red, blue and purple America: The future of election demographics, 50-78. 
Block, J. (1995). A contrarian view of the five-factor approach to personality description. Psychological Bulletin, 117, 187-215.

Bisgaard, M. (2019). How getting the facts right can fuel partisan-motivated reasoning. American Journal of Political Science, 63(4), 824-839.

Bisgaard, M., \& Slothuus, R. (2018). Partisan elites as culprits? How party cues shape partisan perceptual gaps. American Journal of Political Science, 62(2), 456-469.

Blondel, J. (1987). Political leadership. London: Sage.

Bobbio, N. (1996). Left and right. Cambridge, UK: Polity Press.

Bond, R., \& Messing, S. (2015). Quantifying Social Media’s Political Space: Estimating Ideology from Publicly Revealed Preferences on Facebook. American Political Science Review, 109(1), 6278. doi:10.1017/S0003055414000525

Boston, J., Homola, J., Sinclair, B., Torres, M., \& Tucker, P. D. (2018). The dynamic relationship between personality stability and political attitudes. Public Opinion Quarterly, 82(S1), 843-865.

Bullock, J. G., A. S. Gerber, S. J. Hill, \& G. A. Huber. (2015). Partisan bias in factual beliefs about politics. Quarterly Journal of Political Science (10), 519-78.

Bullock, J. G., \& Lenz, G. (2019). Partisan bias in surveys. Annual Review of Political Science, 22, 325342.

Braithwaite, V. (1997). Harmony and security value orientations in political evaluation. Personality and Social Psychology Bulletin, 23, 401-414.

Brader, T. A., \& Tucker, J. A. (2012). Survey experiments: Partisan cues in multi-party systems. Experimental Political Science, 112-139.

Brandt, M. J., \& Crawford, J. T. (2020). Worldview conflict and prejudice. Advances in Experimental Social Psychology, 61, 1-66. 
Brandt, M. J., Reyna, C., Chambers, J. R., Crawford, J. T., \& Wetherell, G. (2014). The ideologicalconflict hypothesis: Intolerance among both liberals and conservatives. Current Directions in Psychological Science, 23(1), 27-34.

Brandt, M. J., Sibley, C., \& Osborne, D. (2019). What is central to belief system networks. Personality and Social Psychology Bulletin, 45, 1352-1364.

Brandt, M. J., \& Sleegers, W. W. A. (2021). Evaluating belief system networks as a theory of political belief system dynamics. Personality and Social Psychology Review, 25, 159-185.

Brandt, M. J., Turner-Zwinkels, F. M., Karapirinler, B., Van Leeuwen, F., Bender, M., van Osch, Y., \& Adams, B. (2021). The association between threat and politics depends on the type of threat, the political domain, and the country. Personality and Social Psychology Bulletin, 47(2), $324-343$.

Brewer, M. B. (2001). The many faces of social identity: Implications for political psychology. Political psychology, 22(1), 115-125.

Campbell, A., Converse, P., Miller, W., \& Stokes, W. (1960). The American voter. New York: Wiley.

Caprara, G. V., Schwartz, S., Capanna, C., Vecchione, M., \& Barbaranelli, C. (2006). Personality and politics: Values, traits, and political choice. Political Psychology, 27, 1-28.

Caprara, G. V., \& Zimbardo, P. G. (2004). Personalizing politics: a congruency model of political preference. American Psychologist, 59(7), 581.

Carmines, E. G., \& D’Amico, N. J. (2015). The new look in political ideology research. Annual Review of Political Science, 18, 206-215.

Carmines, E. G., Ensley, M. J., \& Wagner, M. W. (2012). Political ideology in American politics: One, two, or none? The Forum, 10, 1-18.

Carmines, E. G., Ensley, M. J., \& Wagner, M. W. (2016). Ideological heterogeneity and the rise of Donald Trump. In The Forum, Vol. 14, No. 4, 385-397). De Gruyter. 
Carmines, E. G., \& Stimson, J. A. (1980). The two faces of issue voting. The American Political Science Review, 74(1), 78-91.

Carney, D.R., Jost, J.T., Gosling, S.D., \& Potter, J. (2008). The secret lives of liberals and conservatives: Personality profiles, interaction styles, and the things they leave behind. Political Psychology, 29, 807-840.

Chaiken, S., \& Ledgerwood, A. (2012). A theory of heuristic and systematic information processing. In P. A. M. Van Lange, A. W. Kruglanski, \& E. T. Higgins (Eds.), Handbook of theories of social psychology (p. 246-266). Thousand Oaks, CA: Sage Publications Ltd.

Charney, E. (2008). Genes and ideologies. Perspectives on Politics, 6, 299-319.

Chirumbolo, A., Areni, A., \& Sensales, G. (2004). Need for cognitive closure and politics: Voting, political attitudes and attributional style. International Journal of Psychology, 39, 245-253.

Cizmar, A. M., Layman, G. C., Mc'Tague, J., Pearson-Merkowitz, S., \& Spivey, M. (2014). Authoritarianism and American political behavior from 1952 to 2008. Political Research Quarterly, 67(1), 71-83.

Claassen, C. (2020). Does public support help democracy survive? American Journal of Political Science, 64(1), 118-134.

Clifford, S., Jewell, R., \& Waggoner, P. (2015). Are samples drawn from Mechanical Turk valid for research on political ideology? Research \& Politics, October-December, 1-9

Cohen, G. L. (2003). Party Over Policy: The dominating impact of group influence on political beliefs. Journal of Personality and Social Psychology, 85, 808-822.

Collins, T. P., Crawford, J. T., \& Brandt, M. J. (2017). No evidence for ideological asymmetry in dissonance avoidance. Social Psychology, 48, 123-134. doi:10.1027/1864-9335/a000300

Converse, P. (1964). The nature of belief systems in mass publics. In D. Apter (Ed.), Ideology and Discontent. New York: Free Press. 
Converse, P. E. (2006). Democratic theory and electoral reality. Critical Review, 18, 75-104.

Conway III, L. G., Gornick, L. J., Houck, S. C., Anderson, C., Stockert, J., Sessoms, D., \& McCue, K. (2016). Are conservatives really more simple-minded than liberals? The domain specificity of complex thinking. Political Psychology, 37(6), 777-798.

Conway III, L. G., Houck, S. C., Gornick, L. J., \& Repke, M. A. (2018). Finding the Loch Ness monster: Left-wing authoritarianism in the United States. Political Psychology, 39, 1049-1067.

Cooper, J., Zanna, M. P., \& Goethals, G. R. (1974). Mistreatment of an esteemed other as a consequence affecting dissonance reduction. Journal of Experimental Social Psychology, 10(3), 224-233.

Cooper, J., \& Fazio, R. H. (1984). A New Look at Dissonance Theory. Advances in Experimental Social Psychology, 17(C), 229-266. doi:10.1016/S0065-2601(08)60121-5

Coppock, A., \& Green, D. P. (2020). Do belief systems exhibit dynamic constraint? Journal of Politics.

Costello, T.H., Bowes, S.M., Stevens, S.T., Waldman, I.W., Tasimi, A., \& Lilienfeld, S.O. (2021). Clarifying the structure and nature of left-wing authoritarianism. Journal of Personality and Social Psychology.

Cowan, S. K., \& Baldassarri, D. (2018). "It could turn ugly": Selective disclosure of attitudes in political discussion networks. Social Networks, 52, 1-17.

Crawford, J. T. (2017). Are conservatives more sensitive to threat than liberals? It depends on how we define threat and conservatism. Social Cognition, 35(4), 354-373.

Crawford, J. T., \& Pilanski, J. M. (2014). Political intolerance, right and left. Political Psychology, 35(6), 841-851. 
Czarnek, G., \& Kossowska, M. (2019, July 6). Welfare state regime and political engagement modify the relationship between openness and economic beliefs. https://doi.org/10.31234/osf.io/q4uks

Dang, J., King, K. M., \& Inzlicht, M. (2020). Why are self-report and behavioral measures weakly correlated? Trends in Cognitive Sciences, 24, 267-269.

Dahl, R. A. (2008). Polyarchy: Participation and opposition. Yale University Press.

Deaux, K. (1996). Social identification. In E. T. Higgins \& A. W. Kruglanski (Eds.), Social psychology: Handbook of basic principles (p. 777-798). New York: The Guilford Press.

Denzau, A. D, \& North, D.C. (1994/2000). Shared mental models: ideologies and institutions. In A. Lupia, M.C. McCubbins, \& S. L. Popkin (Eds.), Elements of Reason: Cognition, Choice, and the Bounds of Rationality (pp. 23-46). New York: Cambridge University Press.

Ditto, P. H., Liu, B. S., Clark, C. J., Wojcik, S. P., Chen, E. E., Grady, R.H., . . Zinger, J. F. (2019). At least bias is bipartisan: A meta-analytic comparison of partisan bias in liberals and conservatives. Perspectives on Psychological Science, 14, 273-291. http:/ / dx.doi.org/10.1177/ 1745691617746796

Downs, A. (1957). An economic theory of democracy. New York: Harper and Row.

Druckman, J. N., Peterson, E., \& Slothuus, R. (2013). How elite partisan polarization affects public opinion formation. American Political Science Review, 107, 57-79.

Drutman L, Goldman, L. \& Diamond, L. (2018) Follow the leader: Exploring American support for democracy and authoritarianism. (Democracy Fund Voter Study Group Rep., 2018). https://www.voterstudygroup.org/publication/follow-the-leader.

Duckitt, J. (2001). A dual process cognitive-motivational theory of ideology and prejudice. Advances in Experimental Social Psychology, 22, 41-113.

Duckitt, J., \& Sibley, C. G. (2009). A dual-process motivational model of ideology, politics, and 
prejudice. Psychological Inquiry, 20(2-3), 98-109.

Duckitt, J., \& Bizumic, B. (2013). Multidimensionality of right-wing authoritarian attitudes: Authoritarianism-conservatism-traditionalism. Political Psychology, 34, 841-862. doi:10.1111/pops.12022

Duckitt, J., \& Sibley, C. G. (2010). Personality, ideology, prejudice, and politics: A dual process motivational model. Journal of Personality, 78, 1861-1894.

Duriez, B., Van Hiel, A., \& Kossowska, M. (2005). Authoritarianism and social dominance in Western and Eastern Europe: The importance of the sociopolitical context and of political interest and involvement. Political Psychology, 26(2), 299-320.

Dusso, A. (2017). Race and Right-Wing Authoritarianism: How Scoring High in Authoritarianism Does Not Necessarily Lead to Support for Right-Wing Candidates. Social Science Quarterly, 98(1), 244-260.

Eagly, A. H., \& Chaiken, S. (1993). The psychology of attitudes. Harcourt Brace Jovanovich College Publishers.

Echterhoff, G., Higgins, E. T., \& Groll, S. (2005). Audience-tuning effects on memory: the role of shared reality. Journal of Personality and Social Psychology, 89(3), 257-276

Egan, P. J. (2020). identity as dependent variable: How Americans shift their identities to align with their politics. American Journal of Political Science, 64, 699-716.

Eichmeier, A., \& Stenhouse, N. (2019). Differences that don't make much different: Party asymmetry in open-minded cognitive styles has little relationship to information processing behavior. Research \& Politics, July-September 2019, 1-9.

Ellis, C., \& Stimson, J. A. (2012). Ideology in America. New York, NY: Cambridge University Press. Enos, R. D. (2017). The space between us: Social geography and politics. Cambridge University Press. Erikson, R. S. (1979). The SRC panel data and mass political attitudes. British Journal of 
Ideology -63

Political Science, 9, 89-114.

Erikson, R. S., \& Tedin, K. L. (2003). American public opinion (6 $6^{\text {th }}$ ed.). New York: Longman.

Evans, G., Heath, A., \& Lalljee, M. (1996). Measuring left-right and libertarian-authoritarian values in the British electorate. British Journal of Sociology, 47, 93-112.

Eysenck, H. J. (1954). The psychology of politics. New York: Praeger.

Fails, M. D., \& Pierce, H. N. (2010). Changing mass attitudes and democratic deepening. Political Research Quarterly, 63(1), 174-187.

Federico, C. M. (2020). Ideology and public opinion. In A. Berinsky (Ed.), New directions in public opinion (3rd ed., pp. 75-98). New York: Routledge.

Federico, C. M. (2021). The personality basis of political preferences. In D. Osborne \& C. G. Sibley (Eds.), The Cambridge handbook of political psychology. Cambridge: Cambridge University Press. Preprint: 10.31234/osf.io/87c3y

Federico, C. M., Deason, G., \& Fisher, E. L. (2012). Ideological asymmetry in the relationship between epistemic motivation and political attitudes. Journal of Personality and Social Psychology, 103, 381-398. doi: 10.1037/a0029063

Federico, C. M., \& Ekstrom, P. D. (2018). The political self: How identity aligns preferences with epistemic needs. Psychological Science, 29, 901-913. doi: 10.1177/0956797617748679

Federico, C. M., Ergun, D., \& Hunt, C. V. (2014). Opposition to equality and support for tradition as mediators of the relationship between epistemic motivation and system-justifying identifications. Group Processes \& Intergroup Relations, 17, 524-541 doi: $10.1177 / 1368430213517273$

Federico, C.M., Fisher, E.L., \& Deason, G. (2011). Expertise and the ideological consequences of the authoritarian predisposition. Public Opinion Quarterly, 75, 686-708. 
Federico, C. M., \& Goren, P. (2009). Motivated social cognition and ideology: Is attention to elite discourse a prerequisite for epistemically motivated political affinities? In J. T. Jost, A. C. Kay, and H. Thorisdottir (Eds.), Social and psychological bases of ideology and system justification (pp. 267-291). New York: Oxford University Press.

Federico, C. M., Hunt, C. V., \& Ergun, D. (2009). Political expertise, social worldviews, and ideology: Translating "competitive jungles" and "dangerous worlds" into ideological reality. Social Justice Research, 22(2-3), 259-279.

Federico, C. M., Johnston, C. D., \& Lavine, H. G. (2014). Context, engagement, and the (multiple) functions of negativity bias. Behavioral and Brain Sciences, 37(03), 311-312.

Federico, C. M., \& Malka, A. (2018). The contingent, contextual nature of the relationship between needs for security and certainty and political preferences: Evidence and implications. Advances in Political Psychology, S1, 3-48. doi: 10.1111/pops.12477

Federico, C. M., \& Reifen Tagar, M. (2014). Zeroing in on the right: Education and the partisan expression of authoritarianism. Political Behavior, 36, 581-603. doi: 10.1007/s11109-013-92504

Feinberg, M., \& Willer, R. (2013). The moral roots of environmental attitudes. Psychological science, 24(1), 56-62.

Feldman, S. (2003). Enforcing social conformity: A theory of authoritarianism." Political Psychology, $24,41-74$.

Feldman, S. (2013). Political ideology. In L. Huddy, D. O. Sears, \& J. S. Levy (Eds.), The Oxford handbook of political psychology (p. 591-626). Oxford University Press.

Feldman, S., \& Johnston, C. (2014). Understanding the determinants of political ideology: Implications of structural complexity. Political Psychology, 35(3), 337-358.

Fiagbenu, M. E., Proch, J., \& Kessler, T. (2019). Of deadly beans and risky stocks: Political ideology 
Ideology -65

and attitude formation via exploration depend on the nature of the attitude stimuli. British Journal of Psychology, 112, 342-357. doi: https://doi.org/10.1111/bjop.12430

Fiorina, M. P. (1976). The voting decision: instrumental and expressive aspects. The journal of politics, $38(2), 390-413$.

Fleishman, J. A. (1988). Attitude organization in the general public: Evidence for a bidimensional structure. Social Forces, 67, 159-184.

Fournier, P., Soroka, S., \& Nir, L. (2020). Negativity biases and political ideology: A comparative test across 17 countries. American Political Science Review, 114(3), 775-791. doi:10.1017/S0003055420000131

Free, L. A., \& Cantril, H. (1967). The political beliefs of Americans. New Brunswick, NJ: Rutgers University Press.

Freeder, S., Lenz, G. S., \& Turney, S. (2019). "he Importance of Knowing 'What Goes with What': Reinterpreting the Evidence on Policy Attitude Stability. Journal of Politics, 81, 274-290

Frimer, J. A., Skitka, L. J., \& Motyl, M. (2017). Liberals and conservatives are similarly motivated to avoid exposure to one another's opinions. Journal of Experimental Social Psychology, 72, 1-12. http://dx.doi.org/10.1016/j.jesp.2017.04.003

Gerber, A. S., Huber, G. A., Doherty, D., Dowling, C. M., \& Ha, S. E. (2010). Personality and political attitudes: Relationships across issue domains and political contexts. American Political Science Review, 104(01), 111-133.

Gerber, A. S., Huber, G. A., Doherty, D., \& Dowling, C. M. (2011). The Big Five personality traits in the political arena. Annual Review of Political Science, 14, 265-287.

Gerber, A. S., Huber, G. A., Doherty, D., \& Dowling, C. M. (2012). Personality and the strength and direction of partisan identification. Political Behavior, 34(4), 653-688.

Gerth, H., \& Mills, C. W. (1953). Character and social structure. New York: Harcourt, Brace, \& 
World.

Gidron, N. (2020). Many ways to be right: Cross-pressured voters in Western Europe. British Journal of Political Science. doi: https://doi.org/10.1017/S0007123420000228.

Gidron, N., \& Ziblatt, D. (2019). Center-right political parties in advanced democracies. Annual Review of Political Science, 22, 17-35.

Goren, P. (2012). On voter competence. New York: Oxford University Press.

Graham, J., Haidt, J., \& Nosek, B. (2009). Liberals and conservatives use different sets of moral foundations. Journal of Personality and Social Psychology, 96, 1029-1046.

Graham, M. H., \& Svolik, M. W. (2020). Democracy in America? Partisanship, polarization, and the robustness of support for democracy in the United States. American Political Science Review, 114(2), 392-409.

Gramsci, A. (1971). Selections from the prison notebooks. New York: International Publishers. (Original work published 1948)

Green, D. P., Palmquist, B., \& Schickler, E. (2002). Partisan hearts and minds. New Haven, CT: Yale University Press.

Groenendyk, E. (2013). Competing motives in the partisan mind: How loyalty and responsiveness shape party identification and democracy. New York: Oxford University Press.

Groenendyk, E. (2018). Competing motives in a polarized electorate: political responsiveness, identity defensiveness, and the rise of partisan antipathy. Political Psychology, 39, 159-171.

Groenendyk, E. W., Kimbrough, E. O., and Pickup, M. (2020). How Norms Shape the Nature and Origins of Mass Belief Systems. Available at SSRN: http://dx.doi.org/10.2139/ssrn.3541289

Groenendyk, E., \& Krupnikov, Y. (2021). What Motivates Reasoning? A Theory of GoalDependent Political Evaluation. American Journal of Political Science, 65(1), 180-196.

Guay, B., \& Johnston, C. (2020). Ideological asymmetries and the determinants of politically 
motivated reasoning. American Journal of Political Science.

Haas, I. J., Jones, C. R., \& Fazio, R. H. (2019). Social Identity and the Use of Ideological Categorization in Political Evaluation. Journal of Social and Political Psychology, 7(1), 335-353.

Habermas, J. (1989). The theory of communicative action, volume two. Boston: Beacon Press.

Haidt, J. (2012). The righteous mind: Why good people are divided by politics and religion. New York, NY: Random House.

Hamlin, A., \& Jennings, C. (2011). Expressive political behaviour: Foundations, scope and implications. British Journal of Political Science, 645-670.

Hamlin, A., \& Jennings, C. (2018). Expressive voting. The Oxford Handbook of Public Choice, 1, 333.

Hardin, C. D., \& Higgins, E. T. (1996). Shared reality: How social verification makes the subjective objective. In E. T. Higgins \& R. M. Sorrentino (Eds.), Handbook of motivation and cognition: The interpersonal context Vol. 3, 28-84.

Harper, C. A. (2020, March 19). Ideological measurement in social and personality psychological science. https://doi.org/10.31234/osf.io/wpsje

Harteveld, E., Kokkonen, A., \& Dahlberg, S. (2017). Adapting to party lines: the effect of party affiliation on attitudes to immigration. West European Politics, 40(6), 1177-1197.

Hatemi, P. K., \& McDermott, R. (2020). Dispositional Fear and Political Attitudes. Human Nature, 119.

Heider, F. (1958). The psychology of interpersonal relations. New York: John Wiley \& Sons Inc.

Hennes, E. P., Nam, H. H., Stern, C., \& Jost, J. T. (2012). Not all ideologies are created equal: Epistemic, existential, and relational needs predict system-justifying attitudes. Social Cognition, 30(6), 669-688.

Hetherington, M. J., \& Weiler, J. D. (2009). Authoritarianism and polarization in American politics. New York, NY: Cambridge University Press. 
Heywood, A. (2007). Political ideologies (4 $4^{\text {th }}$ edition). New York: Palgrave Macmillan

Hibbing, J. R., Smith, K. B., \& Alford, J. R. (2014). Predisposed: Liberals, conservatives, and the biology of political differences. New York: Routledge

Hill, J. L., \& Kriesi, H. (2001). An extension and test of Converse's "black-and-white" model of response stability. American Political Science Review, 95, 397-413.

Hinich, M. J., \& Munger, M.C. (1994). Ideology and the theory of political choice. Ann Arbor, MI: University of Michigan Press.

Hobolt, S. B., Leeper, T. J., \& Tilley, J. (2020). Divided by the vote: Affective polarization in the wake of the Brexit referendum. British Journal of Political Science, 1-18.

Hogg, M. A., Terry, D. J., \& White, K. M. (1995). A tale of two theories: A critical comparison of identity theory with social identity theory. Social psychology quarterly, 255-269.

Hopkins, D. J., \& Noel, H. (2021). Trump and the Shifting Meaning of "Conservative": Using activists' pairwise comparisons to measure politicians' perceived ideologies. Manuscript in preparation.

Huber, G. A., \& Malhotra, N. (2017). Political homophily in social relationships: Evidence from online dating behavior. The Journal of Politics, 79(1), 269-283.

Huckfeldt, R., Johnson, P. E., \& Sprague, J. (2004). Political disagreement: The survival of diverse opinions within communication networks. New York: Cambridge University Press.

Huddy, L. (2001). From social to political identity: a critical examination of social identity theory. Political Psychology 22, 127-156

Huddy, L., \& Bankert, A. (2017). Political partisanship as a social identity. Oxford research encyclopedia of politics.

Huddy, L., Bankert, A., \& Davies, C. (2018). Expressive versus instrumental partisanship in multiparty European systems. Political Psychology, 39, 173-199.

Huddy, L., Mason, L., \& Aaroe, L. (2015). Expressive partisanship: Campaign involvement, political 
emotion, and partisan identity. American Political Science Review, 109, 1-17.

Inglehart, R. (2003). How solid is mass support for democracy, And how can we measure it? PS: Political Science and Politics, 36(1), 51-57.

Inglehart, R., \& Norris. P. (2019). Cultural backlash: Trump, Brexit and authoritarian populism. Cambridge: Cambridge University Press.

Iyengar, S., Konitzer, T., \& Tedin, K. (2018). The home as a political fortress: Family agreement in an era of polarization. Journal of Politics, 80(4), 1326-1338.

Jennings, M. K. (1992). Ideological thinking among mass publics and political elites. Public Opinion Quarterly, 56, 419-441.

Jennings, M. K., \& Niemi, R. G. (1968). The transmission of political values from parent to child. American Political Science Review, 62(1), 169-184.

Jennings M. K., \& Niemi R. G. (1981). Generations and politics: A panel study of young adults and their Parents. Princeton: Princeton University Press

Johnston, C. D., Lavine, H. G., \& Federico, C. M. (2017). Open versus closed: Personality, identity, and the politics of redistribution. Cambridge, UK: Cambridge University Press.

Johnston, C. D., \& Wronski, J. (2015). Personality dispositions and political preferences across hard and easy issues. Political Psychology, 36(1), 35-53.

Jost, J. T. (2006). The end of the end of ideology. American Psychologist, 61, 651-670. https://doi.org/10.1037/0003-066X.61.7.651

Jost, J. T. (2009). Elective affinities: on the psychological bases of left-right differences. Psychological Inquiry, 20, 129-141

Jost, J. T. (2017). Ideological asymmetries and the essence of political psychology. Political Psychology, 38, 167-208. https://doi.org/10.1111/pops.12407 
Ideology -70

Jost, J. T., Federico, C. M. \& Napier, J. L. (2009). Political Ideology: Its structure, functions, and elective affinities. Annual Review of Psychology, 60, 307-333.

Jost, J. T., Federico, C. M., \& Napier, J. L. (2013). Political ideologies and their social psychological functions. In M. Freeden, L. T. Sargent, \& M. Stears (Eds.), Handbook of Political Ideologies (pp. 232-250). New York: Oxford University Press.

Jost, J. T., Glaser, J., Kruglanski, A. W., \& Sulloway, F. (2003). Political conservatism as motivated social cognition. Psychological Bulletin, 129, 339-375.

Jost, J.T., Ledgerwood, A. \& Hardin, C.D. (2008), Shared Reality, System Justification, and the Relational Basis of Ideological Beliefs. Social and Personality Psychology Compass, 2, 171186. doi:10.1111/j.1751-9004.2007.00056.x

Jost, J. T., Nosek, B. A., \& Gosling, S. D. (2008). Ideology: Its resurgence in social, personality, and political psychology. Perspectives on Psychological Science, 3(2), 126-136.

Jost, J. T., Sterling, J., \& Stern, C. (2017b). Getting closure on conservatism, or the politics of epistemic and existential motivation. In C. Kopetz \& A. Fishbach (Eds.), The motivationcognition interface; From the lab to the real world: A Festschrift in bonor of Arie W. Kruglanski. New York: Psychology Press.

Jost, J. T., Stern, C., Rule, N. O., \& Sterling, J. (2017a). The politics of fear: Is there an ideological asymmetry in existential motivation? Social Cognition, 35, 324-353.

Judd, C. M., \& Milburn, M. A. (1980). The structure of attitude systems in the general public: Comparisons of a structural equation model. American Sociological Review, 45, 627-643.

Kahan, D. M. (2015). The expressive rationality of inaccurate perceptions. Behavioral \& Brain Sciences, 40, 26-28.

Kahan, D. M. (2015). What is the 'science of science communication'? Journal of Science Communication, 14 (3), 1-12. 
Kalmoe, N. P. (2020). Uses and abuses of ideology in political psychology. Political Psychology.

Kalmoe, N. P., \& Johnston, M (2021). Genes, ideology, and sophistication. Journal of Experimental Political Science. doi:10.1017/XPS.2021.4

Kemmelmeier, M. (1997). Need for closure and political orientation among German university students. Journal of Social Psychology, 137, 787-789, DOI: 10.1080/00224549709595501

Kettle, K. L., \& Salerno, A. (2017). Anger promotes economic conservatism. Personality and Social Psychology Bulletin, 43, 1440-1454.

Kinder, D. R. (2006). Belief systems today. Critical Review, 18, 197-216.

Kinder, D. R., \& Kalmoe, N. P. (2017). Neither liberal nor conservative: Ideological innocence in the American public. University of Chicago Press.

Kitschelt, H., Hawkins, K. A., Luna, J. P., Rosas, G., \& Zechmeister, E. J. (2010). Latin American party systems. Cambridge University Press.

Klofstad, C. A., McDermott, R., \& Hatemi, P. K. (2013). The dating preferences of liberals and conservatives. Political Behavior, 35(3), 519-538.

Knight, K. (1999). Liberalism and conservatism. In J. P. Robinson, P. R. Shaver, \& L.S. Wrightsman (Eds.), Measures of social psychological attitudes (Vol. 2, pp. 59-158). San Diego, CA: Academic Press.

Knoke, D. M. (1979). Stratification and the dimensions of American political orientations. American Journal of Political Science, 23, 772-791.

Koleva, S. P., Graham, J., Iyer, R., Ditto, P. H., \& Haidt, J. (2012). Tracing the threads: How five moral concerns (especially purity) help explain culture war attitudes. Journal of Research in Personality, 46, 184-194.

Kossowska, M. \& Van Hiel, A. (2003). The relationship between need for closure and conservative beliefs in western and eastern Europe. Political Psychology, 24, 501-508. 
Krosnick, J. A. (1988). The role of attitude importance in social evaluation: A study of policy preferences, presidential candidate evaluations, and voting behavior. Journal of Personality and Social Psychology, 55, 196-210. doi:10.1037//0022-3514.55.2.196

Kruglanski, A. W. (2004). The psychology of closed-mindedness. New York: Psychology Press.

Kruglanski, A.W., Pierro, A., Mannetti, L.,\& DeGrada, E. (2006). Groups as epistemic providers: Need for closure and the unfolding of group centrism. Psychological Review, 113, 84100.

Kruglanski, A. W., \& Webster, D. M. (1996). Motivated closing of the mind: "Seizing” and "freezing." Psychological Review, 103, 263-283.

Ksiazkiewicz, A., \& Friesen, A. (2017). Genes and politics. In S. A. Peterson \& A. Somit (Eds.) Handbook of Biology and Politics (pp. 85-105). Northampton, MA: Elgar Publishing.

Kunda, Z. (1990). The case for motivated reasoning. Psychological Bulletin, 108, 480-498.

Kunst, J. R., Dovidio, J. F., \& Thomsen, L. (2019). Fusion with political leaders predicts willingness to persecute immigrants and political opponents. Nature Human Behaviour, 3(11), 1180-1189.

Lammers, J., Koch, A., Conway, P., \& Brandt, M. J. (2017). The political domain appears simpler to the politically extreme than to political moderates. Social Psychological \& Personality Science, 8 , 612-622. http:/ /dx.doi.org/10.1177/1948550616678456

Laponce, J. A. (1981). Left and right: The topography of political perceptions. Toronto: University of Toronto Press.

Lasswell, H. D. (1948). Power and personality. New York: Norton.

Lauderdale, B. E. (2016). Partisan disagreements arising from rationalization of common information. Political Science Research and Methods, 4(3), 477-492.

Lavine, H., Burgess, D. M. Snyder, J. Transue, J.L. Sullivan, B. Haney, and S.H. Wagner. (1999). Threat, authoritarianism, and voting: An investigation of personality and persuasion. 
Personality and Social Psychology Bulletin, 25, 337-347.

Lavine, H. G., Johnston, C. D., \& Steenbergen, M. R. (2012). The ambivalent partisan: How critical loyalty promotes democracy. New York: Oxford University Press.

Lavine, H., Lodge, M., Polichak, J., \& Taber, C. (2002). Explicating the black box through experimentation: Studies of authoritarianism and threat. Political Analysis, 10, 342-360.

Layman, G. (2001). The great divide: Religious and cultural conflict in American party politics.

New York: Columbia University Press.

Layman, G. C., \& Carsey, T. M. (2002). Party polarization and "conflict extension" in the American electorate. American Journal of Political Science, 46, 786-802.

Lee, F. L. (2016). Impact of social media on opinion polarization in varying times. Communication and the Public, 1(1), 56-71.

Lee, J. K., Choi, J., Kim, C., \& Kim, Y. (2014). Social media, network heterogeneity, and opinion polarization. Journal of communication, 64(4), 702-722.

Lees, J., \& Cikara, M. (2020). Inaccurate group meta-perceptions drive negative out-group attributions in competitive contexts. Nature human behaviour, 4(3), 279-286.

Leeper, T. J., \& Slothuus, R. (2014). Political parties, motivated reasoning, and public opinion formation. Political Psychology, 35, 129-156.

Lefkofridi, Z., Wagner, M., \& Willmann, J. E. (2014). Left-authoritarians and policy representation in Western Europe: Electoral choice across ideological dimensions. West European Politics, 37(1), 65-90.

Lefkofridi, Z., \& Michel, E. (2017). The Electoral Politics of Solidarity: The Welfare Agendas of Radical Right Parties. In K. Banting \& W. Kymlicka (eds.), The Strains of Commitment: The Political Sources of Solidarity in Diverse Societies (233-267). Oxford: Oxford University Press

Levendusky, M. (2009). The partisan sort: How liberals became Democrats and conservatives 
Ideology -74

became Republicans. Chicago: University of Chicago Press.

Levendusky, M. S. (2018). Americans, not partisans: Can priming American national identity reduce affective polarization?. The Journal of Politics, 80(1), 59-70.

Lewis, V. (2019). The problem of Donald Trump and the static spectrum fallacy. Party Politics. doi: $10.1177 / 1354068819871673$.

Lijphart, A. (1990). Electoral systems and party systems: A study of twenty-seven democracies, 1945-1990. Oxford: Oxford University Press.

Lipset, S. M. (1959). Some social requisites of democracy: Economic development and political legitimacy. The American political science review, 53(1), 69-105.

Lipset, S. M. (1960). Political man. New York: Doubleday.

Lipset, S. M., Rokkan, S., eds. (1967). Party systems and voter alignments: Cross-national perspectives. New York: Free Press.

Lodge, M., \& Taber, C. S. (2013). The rationalizing voter. New York: Cambridge University Press.

Ludeke, S., Johnson, W., \& Bouchard Jr, T. J. (2013). “Obedience to traditional authority:” A heritable factor underlying authoritarianism, conservatism and religiousness. Personality and Individual Differences, 55(4), 375-380.

Lupia, A., \& McCubbins, M. D. (1998). Political credibility and economic reform. A Report for the World Bank.

Luttig, M. D. (2018). The 'prejudiced personality' and the origins of partisan strength, affective polarization, and partisan sorting. Advances in Political Psychology, 39.S1, 239-256.

Luttig, M. D. (2021). Reconsidering the relationship between authoritarianism and Republican support in 2016 and beyond. Journal of Politics, 83(2), 783-787.

MacWilliams, M. C. (2016). Who decides when the party doesn't? Authoritarian voters and the rise of Donald Trump. PS: Political Science \& Politics, 49(4), 716-721. 
Malka, A. (2013). Religion and domestic political attitudes around the world. V. Saroglou (Ed.), Religion, Personality, and Social Behavior, 230-254. New York: Taylor \& Francis.

Malka, A., \& Lelkes, Y. (2017, August 10). In a new poll, half of Republicans say they would support postponing the 2020 election if Trump proposed it. Washington Post. https://www.washingtonpost.com/news/monkey-cage/wp/2017/08/10/in-a-new-pollhalf-of-republicans-say-they-would-support-postponing-the-2020-election-if-trumpproposed-it/

Malka, A., \& Adelman, M. (under review). Expressive survey responding: A closer look at the evidence and its implications for American democracy.

Malka, A., \& Costello, T. H. (under review). Professed Democracy Support and Openness to Politically Congenial Authoritarian Actions in the American Public.

Malka, A., \& Lelkes, Y. (2010). More than ideology: Conservative-liberal identity and receptivity to political cues. Social Justice Research, 23(2), 156-188.

Malka, A., Lelkes, Y., \& Holzer, N. (2017). Rethinking the rigidity of the right model: Three suboptimal methodological practices and their implications. In J. T. Crawford, \& L. Jussim (Eds.) Frontiers of Social Psychology: Politics of Social Psychology (pp. 116-135). Psychology Press: New York.

Malka, A., Lelkes, Y., \& Soto, C.J. (2019). Are cultural and economic conservatism positively correlated? A large-scale cross-national test. British Journal of Political Science, 49, 1045-1069. doi:10.1017/S0007123417000072, 1-25.

Malka, A., Lelkes, Y., Bakker, B. N., \& Spivack, E. (2020). Who is Open to Authoritarian Governance within Western Democracies? Perspectives on Politics, 1-20.

Malka, A., \& Soto, C. J. (2015). Rigidity of the economic right? Menu-independent and menudependent influences of psychological dispositions on political attitudes. Current Directions 
in Psychological Science, 24, 137-142. https:/ /doi.org/10.1177/0963721414556340Malka, A.,

Malka, A., Soto, C. J., Inzlicht, M., \& Lelkes, Y. (2014). Do needs for security and certainty

predict cultural and economic conservatism? A cross-national analysis. Journal of personality and social psychology, 106(6), 1031.

Mallinas, S. R., Crawford, J. T., \& Cole, S. (2018). Political opposites do not attract: The effects of ideological dissimilarity on impression formation. Journal of Social and Political Psychology, 6(1), 49-75. doi:10.5964/jspp.v6i1.747

Margolis, M. F. (2018a). How politics affects religion: Partisanship, socialization, and religiosity in America. The Journal of Politics, 80(1), 30-43.

Margolis, M. F. (2018b). From politics to the pews: How partisanship and the political environment shape religious identity. Chicago: University of Chicago Press.

Martin, G. J., \& Webster, S. W. (2020). Does residential sorting explain geographic polarization?. Political Science Research and Methods, 8(2), 215-231.

Marx, K., \& Engels, F. (1970). The German ideology. (C. J. Arthur, Trans.). New York: International Publishers. (Original work published 1846).

Mason, L. (2018). Uncivil agreement: How politics became our identity. Chicago: University of Chicago Press.

Mason, L., \& Wronski, J. (2018). One tribe to bind them all: How our social group attachments strengthen partisanship. Political Psychology, 39 (S1), 257-277.

McCarty, N., Poole, K. T., \& Rosenthal, H. (2006). Polarized America. Cambridge, MA: MIT Press.

McClosky, H. (1958). Conservatism and personality. American Political Science Review, 52, 27-45. McClosky, H., \& Zaller, J. (1984). The American ethos. Harvard University Press.

McCoy, J., Rahman, T., \& Somer, M. (2018). Polarization and the global crisis of democracy: 
Common patterns, dynamics, and pernicious consequences for democratic polities. American Behavioral Scientist, 62(1), 16-42.

McCoy, J., Simonovits, G., \& Littvay, L. (2020). Democratic hypocrisy: Polarized citizens support democracy-eroding behavior when their own party is in power.

McCrae, R. R. (1996). Social consequences of experiential openness. Psychological Bulletin, 120, 323337.

McCrae, R. R. \& Costa, P. T., Jr. (2003) Personality in adulthood: A five-factor theory perspective (2 ${ }^{\text {nd }}$ ed.) New York: Guilford Press.

McPhee, W. N., Berelson, B. R., \& Lazarsfeld, P. F. (1986). Voting: a study of opinion formation in a presidential campaign. Chicago: University of Chicago Press.

Merolla, J. L., Stephenson, L. B., \& Zechmeister, E. J. (2016). Deciding correctly: variance in the effective use of party cues. Voting Experiments, 19-42.

Miller, S.V. \& Davis, N.T. (2020). The effect of white social prejudice on support for American democracy. Journal of Race, Ethnicity, and Politics, 1-18.

Mondak, J. J. (2010). Personality and the foundations of political behavior. Cambridge University Press. Morgan, G. S., \& Wisneski, D. C. (2017). The structure of political ideology varies within and between people: Implications for theories about ideology's causes. Social Cognition, 35, 395414.

Mummolo, J., \& Nall, C. (2017). Why partisans do not sort: The constraints on political segregation. The Journal of Politics, 79(1), 45-59.

Mutz, D. C. (2006). Hearing the Other Side: Deliberative Versus Participatory Democracy. New York: Cambridge University Press.

Nam, H. H., Jost, J. T., \& Van Bavel, J. J. (2013). “Not for all the tea in China!” Political ideology 
and the avoidance of dissonance-arousing situations. PLOS ONE, 8(4), Article e59837. doi:10.1371/journal.pone.0059837

Newcomb, T. M. (1943) Personality and social change: Attitude formation in a student community. New York: Dryden.

Nicholson, N. R. (2012). A review of social isolation: an important but underassessed condition in older adults. The Journal of Primary Prevention, 33(2-3), 137-152.

Nicholson, S. P., Coe, C. M., Emory, J., \& Song, A. V. (2016). The politics of beauty: The effects of partisan bias on physical attractiveness. Political Behavior, 38(4), 883-898.

Nilsson, A., \& Jost, J. T. (2020). The authoritarian-conservatism nexus. Current Opinion in Behavioral Sciences, 34, 148-154.

Noel, H. (2014). Political ideologies and political parties in America. New York: Cambridge University Press.

Noelle-Neumann, E. (1974). The spiral of silence: a theory of public opinion. Journal of communication, 24(2), 43-51.

Osborne, D., \& Sibley, C. G. (2012). Does personality matter? Openness correlates with vote choice, but particularly for politically sophisticated voters. Journal of Research in Personality, 46 (6), $743-$ 751.

Osborne, D., \& Sibley, C. G. (2015). Within the limits of civic training: Education moderates the relationship between openness and political attitudes. Political Psychology, 36 (3), 295-313.

Osborne, D., \& Sibley, C. G. (2020). Does Openness to Experience predict changes in conservatism? A nine-wave longitudinal investigation into the personality roots to ideology. Journal of Research in Personality, 87, 103979.

Osmundsen, M. Hendry, D. J., Laustsen, S., Smith, K. N., \& Petersen, M. B. (2020). The 
Ideology -79

psychophysiology of political ideology: Replications, reanalysis, and recommendations. Journal of Politics.

Oxley, D.R., Smith, K.B., Alford, J.R., Hibbing, M.V., Miller, M.S., Scalora, M., et al. (2008). Political attitudes vary with physiological traits. Science, 321, 1667-1670.

Page, S., \& Elbeshbishi, S. (2021, February 21). Exclusive: Defeated and impeached, Trump still commands the loyalty of the GOP's voters. USA Today. https://www.usatoday.com/story/news/politics/2021/02/21/exclusive-trump-party-hestill-holds-loyalty-gop-voters/6765406002/

Patrikios, S. (2008). American Republican religion? Disentangling the causal link between religion and politics in the US. Political Behavior, 30(3), 367-389.

Park, B. (2018). How are we apart? Continuity and change in the structure of ideological disagreement in the American public, 1980-2012. Social Forces, 96, 1757-1784.

Pennycook, G., Cheyne, J. A., Koehler, D. J., \& Fugelsang, J. A. (2019). On the belief that beliefs should change according to evidence: Implications for conspiratorial, moral, paranormal, political, religious, and science beliefs. Judgment and Decision Making, 15, 476-498.

Petersen, M. B. (2015). Evolutionary political psychology: On the origin and structure of heuristics and biases in politics. Political Psychology, 36(S1), p. 45-78.

Petersen, M. B., Skov, M., Serritzlew, S., and Ramsoy, T., (2013). Motivated Reasoning and Political Parties: Evidence for Increased Processing in the Face of Party Cues. Political Behavior 35 (4), $831-54$.

Piurko, Y., Schwartz, S. H., \& Davidov, E. (2011). Basic personal values and the meaning of leftright political orientations in 20 countries. Political Psychology, 32(4), 537-561.

Prentice, D. A., Miller, D. T., \& Lightdale, J. R. (1994). Asymmetries in attachments to groups and 
to their members: Distinguishing between common-identity and common-bond groups. Personality and Social Psychology Bulletin, 20(5), 484-493.

Proch, J., Elad-Strenger, J., \& Kessler, T. (2019). Liberalism and Conservatism, for a Change! Rethinking the Association Between Political Orientation and Relation to Societal Change. Political Psychology, 40, 877-903. doi:10.1111/pops.12559

Reicher, S., Haslam, S. A., \& Hopkins, N. (2005). Social identity and the dynamics of leadership: Leaders and followers as collaborative agents in the transformation of social reality. The Leadership Quarterly, 16(4), 547-568.

Robbett, A., Matthews, H. P. (2018) Partisan bias and expressive voting. European Journal of Political Economy, 157, 107-120.

Rodriguez, C. G., Moskowitz, J. P., Salem, R. M., \& Ditto, P. H. (2017). Partisan selective exposure: The role of party, ideology and ideological extremity over time. Translational Issues in Psychological Science, 3, 254-271. doi:10.1037/tps0000121

Roets, A., Cornelis, I., \& Van Hiel, A. (2014). Openness as a predictor of political orientation and conventional and unconventional political activism in Western and Eastern Europe. Journal of personality assessment, 96(1), 53-63.

Rokeach, M. (1960). The open and closed mind. New York, NY: Basic Books.

Rossignac-Milon, M., \& Higgins, E. T. (2018). Epistemic companions: Shared reality development in close relationships. Current opinion in psychology, 23, 66-71.

Ruisch, B. C., Shook, N. J., \& Fazio, R. H. (2020). Of unbiased beans and slanted stocks: Neutral stimuli reveal the fundamental relation between political ideology and exploratory behaviour. British Journal of Psychology. 112: 358-361. doi: 10.1111/bjop.12455

Ruisch, B. C., \& Stern, C. (2021). The confident conservative: Ideological differences in judgment and decision-making confidence. Journal of Experimental Psychology: General, 150(3), 527-544. 
Rummler, O. (2021, April 27). Poll: 50\% of Republicans support GOP over Trump. Axios. https://www.axios.com/trump-approval-rating-republicans-21d8fa7e-8cee-401f-96eb$\underline{85643 \mathrm{a} 422082 . \mathrm{html}}$

Schwartz, S. H. (1992). Universals in the content and structure of values: Theoretical advances and empirical tests in 20 countries. Advances in Experimental Social Psychology, 25, 1-65.

Schwartz, S. H., Caprara, G. V., Vecchione, M., Bain, P., Bianchi, G., Caprara, M. G., Cieciuch, J., Kirmanoglu, H., Baslevent, C., Lönnqvist, J.-E., Mamali, C., Manzi, J., Pavlopoulos, V., Posnova, T., Schoen, H., Silvester, J., Tabernero, C., Torres, C., Verkasalo, M., Vondráková, E., Welzel, C., \& Zaleski, Z. (2014). Basic personal values underlie and give coherence to political values: A cross national study in 15 countries. Political Behavior, 36, 899930. doi: 10.1007/s11109-013-9255-z

Shafer, B. E., \& Claggett, W. J. (1995). The two majorities: The issue context of modern American politics. Baltimore, MD: The John Hopkins University Press.

Shaffer, S. D. (1981). Balance theory and political cognitions. American Politics Quarterly, 9(3), 291-320.

Shook, N. J., \& Fazio, R. H. (2009). Political ideology, exploration of novel stimuli, and attitude formation. Journal of Experimental Social Psychology, 45, 995-8.

Shultziner, D. (2013). Genes and politics: A new explanation and evaluation of twin study results and association studies in political science. Political Analysis, 21, 350-367.

Sidanius, J. (1988). Political sophistication and political deviance: A structural equation examination of context theory. Journal of Personality and Social Psychology, 55(1), 37-51.

Sidanius, J., Kteily, N., Sheehy-Skeffington, J., Ho, A. K., Sibley, C., \& Duriez, B. (2013). You're inferior and not worth our concern: The interface between empathy and social dominance orientation. Journal of Personality, 81(3), 313-323.

Sidanius, J., \& Pratto, F. (1999). Social dominance. New York, NY: Cambridge University Press. 
Slothuus, R. (2016). Assessing the influence of political parties on public opinion: The challenge from pretreatment effects. Political Communication, 33(2), 302-327.

Slothuus, R., \& Bisgaard, M. (2020). How Political Parties Shape Public Opinion in the Real World. American Journal of Political Science.

Smith, K. B., \& Warren, C. (2020). Physiology predicts ideology. Or does it? The current state of political psychophysiology research. Current Opinion in Behavioral Sciences, 34, 88-93. doi: 10.1016/j.cobeha.2020.01.001

Sniderman, P. M., \& Bullock, J. (2004). A consistency theory of public opinion and political choice: The hypothesis of menu dependence. In W. E. Saris \& P. M. Sniderman (Eds.), Studies in public opinion: Attitudes, nonattitudes, measurement error, and change (pp. 337-357). Princeton, NJ: Princeton University Press.

Sniderman, P. M., Brody, R. A., \& Tetlock, P. E. (1991). Reasoning and choice. New York: Cambridge University Press.

Sorace, M., \& Hobolt, S. B. (2020). A tale of two peoples: motivated reasoning in the aftermath of the Brexit Vote. Political Science Research and Methods, 1-18.

Stangor, C., \& Leary, S. P. (2006). Intergroup beliefs: Investigations from the social side. Advances in Experimental Social Psychology, 38, 243-281.

Steffens, N. K., Haslam, S. A., \& Reicher, S. D. (2014). Up close and personal: Evidence that shared social identity is a basis for the 'special'relationship that binds followers to leaders. The Leadership Quarterly, 25(2), 296-313.

Stenner, K. (2005). The authoritarian dynamic. London: Cambridge University Press.

Stern, C., \& Ondish, P. (2018). Political aspects of shared reality. Current Opinion in Psychology, 23, 1114. doi:.1016/j.copsyc.2017.11.004 
Stimson, J. A. (2004). Tides of consent. New York: Cambridge University Press.

Sullivan J. L., Piereson J., \& Marcus G.E. (1983). Political tolerance and American democracy. Chicago: University of Chicago Press.

Svolik MW (2019). Polarization versus democracy. Journal of Democracy, 30(3), 20-32.

Taber, C. S., \& Lodge, M. (2006). Motivated skepticism in the evaluation of political beliefs. American Journal of Political Science, 50(3), 755-769.

Tajfel, H., \& Turner, J. C. (1986). The social identity theory of intergroup behavior. In S.

Worchel \& W. Austin (Eds.), The psychology of intergroup relations (pp. 7-24). Chicago: NelsonHall.

Tappin, B. M., Pennycook, G., \& Rand, D. G. (2020). Thinking clearly about causal inferences of politically motivated reasoning: Why paradigmatic study designs often undermine causal inference. Current Opinion in Behavioral Sciences, 34, 81-87.

Tetlock, P. E. (1984). Cognitive style and political belief systems in the British House of Commons. Journal of Personality and Social Psychology, 46(2), 365-375.

Thoits, P. A., \& Virshup, L. K. (1997). Me's and we's. Self and identity: Fundamental issues, 106-133.

Thorisdottir, H., Jost, J.T., Liviatan, I., \& Shrout, P.E. (2007). Psychological needs and values underlying left-right political orientation: Cross-national evidence from eastern and western Europe. Public Opinion Quarterly, 71, 175-203.

Tilley, J., \& Hobolt, S. B. (2011). Is the government to blame? An experimental test of how partisanship shapes perceptions of performance and responsibility. The journal of politics, 73(2), 316-330.

Tomkins, S. (1963). Left and right: A basic dimension of ideology and personality. In R. W. White (Ed.), The study of lives: Essays on personality in honor of Henry A. Murray (pp. 388-411). New York, NY: Atherton Press. 
Treier, S., \& Hillygus, D. S. (2009). The nature of political ideology in the contemporary electorate. Public Opinion Quarterly, 73, 679-703.

Van Bavel, J. J., \& Pereira, A. (2018). The partisan brain: an identity-based model of political belief. Trends in Cognitive Sciences, 22(3), 213-224. https://doi.org/10.1016/j.tics.2018.01.004

Van Hiel, A., Onraet, E., Crowson, H. M., and Roets, A. (2016). The relationship between rightwing attitudes and cognitive style: a comparison of self-report and behavioural measures of rigidity and intolerance of ambiguity. European Journal of Personality, 30, 523-531. doi: 10.1002/per.2082

Van Hiel, A., Onraet, E., \& De Pauw, S. (2010). The relationship between social-cultural attitudes and behavioral measures of cognitive style: A meta-analytic integration of studies. Journal of Personality, 78, 1765-1799.

Van Hiel, A., Pandelaere, M., \& Duriez, B. (2004). The impact of need for closure on conservative beliefs and racism: Differential mediation by authoritarian submission and authoritarian dominance. Personality and Social Psychology Bulletin, 30(7), 824-837.

van Prooijen, J. W., \& Krouwel, A. P. (2017). Extreme political beliefs predict dogmatic intolerance. Social Psychological \& Personality Science, 8, 292-300. http:/ /dx.doi.org/10.1177/1948550616671403

van Prooijen, J. W., Krouwel, A. P., Boiten, M., \& Eendebak, L. (2015). Fear among the extremes: How political ideology predicts negative emotions and outgroup derogation. Personality and Social Psychology Bulletin, 41, 485-497. http://dx.doi.org/10.1177/0146167215569706 van Prooijen, J. W., \& Krouwel, A. P. M. (2019). Psychological features of extreme political ideologies. Current Directions in Psychological Science. http://dx.doi.org/10.1177/ 0963721418817755

van Prooijen, J. W., Krouwel, A. P. M., \& Emmer, J. (2018). Ideological responses to the EU refugee 
crisis: The left, the right, and the extremes. Social Psychological \& Personality Science, 9, 143-150. http:/ /dx.doi.org/10.1177/1948550617731501

Washburn, A. N., \& Skitka, L. J. (2017). Science denial across the political divide: Liberals and conservatives are similarly motivated to deny attitude-inconsistent science. Social Psychological \& Personality Science, 9, 927-980. https://doi.org/10.1177/1948550617731500

Weber, M. (1948). From Max Weber: Essays in sociology. New York: Oxford University Press.

Weeden, J., \& Kurzban, R. (2014). The hidden agenda of the political mind. Princeton: Princeton University Press.

Welzel, C. (2007). Are levels of democracy affected by mass attitudes? Testing attainment and sustainment effects on democracy. International Political Science Review, 28(4), 397-424.

Williamson, V., Skocpol, T., \& Coggin, J. (2011). The Tea Party and the remaking of Republican conservatism. Perspectives on Politics, 25-43.

Welzel, C., \& Inglehart, R. (2008). The role of ordinary people in democratization. Journal of Democracy, 19(1), 126-140.

Wilson, G. D. (1973). The psychology of conservatism. New York: Academic Press.

Yilmaz, O., \& Saribay, S. A. (2016). An attempt to clarify the link between cognitive style and political ideology: A non-Western replication and extension. Judgment and Decision Making, 11, 287-300.

Yair, O., \& Huber, G. A. (2020). How Robust Is Evidence of Partisan Perceptual Bias in Survey Responses? A New Approach for Studying Expressive Responding. Public Opinion Quarterly, 84(2), 469-492.

Zaller, J. (1992). The nature and origins of mass opinion. New York: Cambridge University Press.

Zmigrod, L. (2020, September 4). A psychology of ideology: Unpacking the psychological structure of ideological thinking. https://doi.org/10.31234/osf.io/ewy9t 
Zmigrod, L., Rentfrow, P. J., \& Robbins, T. W. (2020). The partisan mind: Is extreme political partisanship related to cognitive inflexibility? Journal of Experimental Psychology: General, 149, 407-418.

Zmigrod, L., Eisenberg, I. W., Bissett, P. G., Robbins, T. W. \& Poldrack, R. A. (2021). The cognitive and perceptual correlates of ideological attitudes: a data-driven approach. Royal Society, 376, doi:10.1098/rstb.2020.0424 